\title{
Carcinoembryonic Antigen Gene Family: Molecular Biology and Clinical Perspectives
}

\author{
John A. Thompson, Fritz Grunert, and Wolfgang Zimmermann \\ Institute of Immunobiology, University of Freiburg, Freiburg, Federal Republic of Germany
}

\begin{abstract}
The carcinoembryonic antigen (CEA) gene family belongs to the immunoglobulin supergene family and can be divided into two main subgroups based on sequence comparisons. In humans it is clustered on the long arm of chromosome 19 and consists of approximately 20 genes. The CEA subgroup genes code for CEA and its classical crossreacting antigens, which are mainly membrane-bound, whereas the other subgroup genes encode the pregnancy-specific glycoproteins (PSG), which are secreted. Splice variants of individual genes and differential post-translational modifications of the resulting proteins, e.g., by glycosylation, indicate a high complexity in the number of putative CEA-related molecules. So far, only a limited number of CEArelated antigens in humans have been
\end{abstract}

unequivocally assigned to a specific gene. Rodent CEA-related genes reveal a high sequence divergence and, in part, a completely different domain organization than the human CEA gene family, making it difficult to determine individual gene counterparts. However, rodent CEA-related genes can be assigned to human subgroups based on similarity of expression patterns, which is characteristic for the subgroups. Various functions have been determined for members of the CEA subgroup in vitro, including cell adhesion, bacterial binding, an accessory role for collagen binding or ecto-ATPases activity. Based on all that is known so far on its biology, the clinical outlook for the CEA family has been reassessed.

Key words: turnor marker, pregnancy-specific glycoprotein, mouse, rat, chromosome 19, cell adhesion, ecto-ATPase/C-CAM, CD66, CD67, evolution

\section{INTRODUCTION}

With improvements in modern medicine, life expectancy is continuously increasing. However, this prolongation of life, together with the many negative influences of modern society, has also led to an increase in the number of so-called civilization illnesses. In many industrial countries, after heart disease, cancer is one of the major causes of death, and lung and colonic cancers are the most prevalent types of malignancy (1). Although cancer is not a new disease, certain forms have dramatically increased due to bad habits: e.g., excessive smoking has made lung cancer a major problem and fatrich, low-fiber diets correlate with an increase in colonic cancer. The inherent fear that a tumor may be discovered deters many people from having regular medical examinations, with the result that therapy may often come too late. Improved methods have to be developed whereby malignancies can be recognized earlier and treated more specifically as well as more efficiently. For example, the targeting of cytotoxic substances could help to decrease the dosage and reduce the side effects and should result in higher concentrations at the tumor. In order to achieve this, differences between tumorous and normal tissues have to be exploited.

Earlier studies revealed the existence of certain molecules which were apparently only present in tumors and were later named tumor markers (reviewed in 2). Subsequent investigations showed that tumor markers are not tumor-specific (apart from possible mutant molecular forms, viral proteins, or the idiotypic regions of antigen receptors in B- and T-cell lymphomas) and their potential clinical application was questioned. This holds true for the carcinoembryonic antigen (CEA), which was first described by Gold and Freedman and independently by von Kleist and Burtin to be present in colonic tumors and in fetal gut, but not in normal colonic mucosa (3-5). However, CEA was later found in normal body fluids and in normal colonic mucosa (6-9), although tumor CEA concentrations are on average $>60$ times higher $(10)$. A possible complication for the clinical application of CEA is the existence of a number of closely related crossreacting antigens, which show variable expression patterns, and are found in a variety of normal tissues (summarized in 11).

Nevertheless, measurement of the CEA serum concentrations is an important parameter in the monitoring of patients following tumor resection (reviewed in 12,13). In fact, elevated CEA levels have also been found in other tumors of

Received May 28, 1991; accepted June 11, 1991.

Address reprint requests to Dr. John Thompson, Institute of Immunobiology, University of Freiburg, Stefan-Meier-Strasse 8, D-7800 Freiburg, Germany. 
epithelial origin, e.g., breast, lung, pancreas, etc. (reviewed in 12,14). With the development of monospecific anti-CEA monoclonal antibodies (reviewed in 15 ) reacting with CEA on the surface of tumor cells, radio-immunolocalization of CEA-expressing tumors and their metastases has been successful (16-18). Furthermore, model studies in rodents indicate that anti-CEA monoclonal antibodies may also have a future role in tumor therapy $(19,20)$.

In order to optimize the clinical potential of CEA as a tumor marker or for targeting, a better understanding of this molecule in relation to the already mentioned closely related crossreacting antigens is necessary, since CEA represents the prototype product of a large gene family. Molecular cloning has allowed detailed analysis of this family whose structures and expression patterns are complex. These studies have given some insight into the possible functions of these molecules. We have some indications that other family members may also be of clinical interest. The purpose of this review is to update what is known on the biology of this gene family and report on how this knowledge can lead to improvements in the clinical applications of CEA-related molecules.

\section{SIZE OF THE HUMAN CEA GENE FAMILY}

A number of CEA-related genes, as well as splice variants of individual genes, have been identified by molecular cloning at the cDNA and genomic levels. We have already described the history of CEA cloning in an earlier review to which we refer for details (11). Once the first clones were identified, probes became available for isolation and identification of other CEA-related genes. On comparing sequences, it became obvious that the human CEA gene family can be divided into two main subgroups (Table 1). Within a subgroup, the different members reveal high sequence conservation $(80-95 \%$ similarity of the $\mathrm{N}$ - domain exons at the nucleotide level), whereas between subgroups this conservation is significantly lower $(65-75 \%)$. The CEA subgroup contains the genes which encode CEA and the classical CEAcrossreacting antigens, such as the non-specific crossreacting antigen (NCA), which was first described by von Kleist et al. (21) and by Mach and Pusztaszeri (22), and the biliary glycoprotein 1 (BGP1), first described by Svenberg (23). The PSG subgroup contains the genes encoding the pregnancyspecific glycoproteins (PSG), which were independently discovered by Tatarinov and Masyukevich (24) and Bohn (25). Bohn named this group of proteins "Schwangerschaftsprotein 1 " (SP1), which has also been used as a tumor marker.

After the cloning of numerous CEA-related genes in different laboratories the nomenclature was coordinated at a workshop held in Freiburg, Germany, in 1989 (26) and the list shown in Table 1 is an update from May 1991. So far, maximally 22 different CEA-related genes have been described, with 9 belonging to the CEA subgroup and 13 to the PSG subgroup. However, only 11 different PSG genes have
TABLE 1. Classification of the Human CEA Gene Family

\begin{tabular}{|c|c|}
\hline Old gene or clone name & $\begin{array}{l}\text { New gene or } \\
\text { mRNA name }\end{array}$ \\
\hline \multicolumn{2}{|l|}{ CEA subgroup } \\
\hline CEA $(71,167)$ & CEA \\
\hline $\operatorname{CEA}(95,105,106,135)$ & CEAa \\
\hline CEA (59) & CEAb \\
\hline $\mathrm{NCA}(71,73,74,105,140,141)$ & $\mathrm{NCA}$ \\
\hline hsCGM6 (54), M6 (216), NCA-W272 (53) & CGM6 \\
\hline BGPI (43), TM-1 CEA (44) & $\mathrm{BGPa}$ \\
\hline TM-2 CEA (44) & $\mathrm{BGPb}$ \\
\hline TM-3 CEA (44) & BGPc \\
\hline TM-4 CEA (44) & BGPd \\
\hline $4-22(104)$ & BGPe \\
\hline $4-13(104)$ & BGPf \\
\hline W211 (94) & BGPg \\
\hline W233 (94) & BGPh \\
\hline W239 (94) & $\mathrm{BGPi}$ \\
\hline $\operatorname{hsCGM1}(42), 6 \mathrm{C} 3,6 \mathrm{Al} 1,7 \mathrm{~A} 2,19 \mathrm{HI}{ }^{\mathrm{a}}$ & CGM1 \\
\hline W264 (45), CGM1a & CGMla \\
\hline W282 (45) & CGMlb \\
\hline $\mathrm{CGMIc}^{\star}$ & CGMlc \\
\hline $\operatorname{hsCGM} 2(42), 5 \mathrm{E} 8,7 \mathrm{E} 12^{\mathrm{a}}$ & CGM2 \\
\hline W236 (45) & CGM7 \\
\hline CGM $8^{\mathrm{a}}$ & CGM8 \\
\hline $\mathrm{CGM}^{\mathrm{b}}$ & CGM9 \\
\hline \multicolumn{2}{|l|}{ PSG subgroup } \\
\hline PSBG (42) & PSG1 \\
\hline PSG93 (107), PS $\beta G-D(217)$, hPSP11 (75), & \\
\hline FL-NCA-2 (55), hPS3 (218), PSG $1_{\mathrm{a}}(57)$ & PSG1a \\
\hline PSG16 (107) & PSGIb \\
\hline PS $\beta G-C(217)$ & PSGIc \\
\hline FL-NCA-1 (56), PSG1 $1_{d}(57)$, SG9 (119) & PSGId \\
\hline PSßG-Ci $(37)$, PSG95 $(69,219)$ & PSGle \\
\hline PS $\beta G-D^{\prime}(37)$ & PSGIf \\
\hline PS $\beta G-E(217)$, SG8 (119) & PSG2n \\
\hline pSP1-i (220), hc17 (221), PS35 (222), & \\
\hline hTS $16(118)$, PSG A (37), SG5 (119) & PSG3m \\
\hline PSG4 (61), hsCGM4 (42), hHSP2 (75), FL17 & PSG4 \\
\hline PSG4 (57), hPS133', PSG9 $\left(\right.$ PS $\left._{K \alpha}\right)(63,103)$ & PSG4a \\
\hline PSG5 (61), PS $\beta$ G HL (clone 12-2) (60) & PSG5 \\
\hline FL-NCA-3 (55) & PSG5n \\
\hline PS $\beta$ G HL (clone 22) $(60)$ & PSG5m \\
\hline hsCGM3 (42), FL26 ${ }^{b}$, PSGGB (69) & PSG6 \\
\hline PSG6 (57) & PSG6r \\
\hline hPS12 (58), PSG10 (103) & PSG6s \\
\hline PSG7 $(61)^{a, b, d}$ & PSG7 \\
\hline CGM35 (59), PSG $8^{\mathrm{b}}$ & PSG8 \\
\hline hTS1 (118) & PSG8a \\
\hline PS34 (222), PS $\beta G-G^{c}, P S \beta G$ B (37), PSG7 (223) & PSG11s \\
\hline hPS2 (58), hPS91 ${ }^{\mathrm{c}}$ & PSG $11 \mathrm{w}$ \\
\hline $11^{\mathrm{f}}$ & PSG 12 \\
\hline $18^{\mathrm{f}}$ & PSG13 \\
\hline PSG $14^{b}$ & PSG14 \\
\hline PSG $15^{\mathrm{b}}$ & PSG15 \\
\hline
\end{tabular}

${ }^{a}$ Unpublished results.

${ }^{b}$ Khan, personal communication.

${ }^{\mathrm{C}} \mathrm{Chan}$, personal communication.

${ }^{\mathrm{d}}$ Niemann, personal communication.

Mansfield, personal communication.

tHardman, personal communication. 
been determined so far with some certainty, i.e., through comparison of the N-terminal domain sequences. For PSG 12 and PSG13, this information is lacking as sequence data only exists from internal domains for these genes. It cannot be certain that they represent separate genes, as they could correspond to PSG14 and PSG15, where only sequence data from the $\mathrm{N}$-terminal domains are available. Indeed, an attempt has recently been made to characterize all PSG subgroup genes and it was concluded that maximally 11 genes exist ( $S$. Hammarström, personal communication). It is obvious from Table 1 that the CEA family is very complex. Not only do a large number of genes exist, for which in the majority of cases transcripts have been identified, but also splice variants of individual genes have been found (e.g., BGP, CGM1, PSG1, etc.), which increase the possible number of different proteins. RNA splice or polyadenylation variants are designated by lowercase letters after the gene name, e.g., PSGla, PSG1b, etc. In some cases, only minor sequence differences have been found, whereby allelic variants of one gene are assumed to occur. As will be discussed below, post-translational modifications, such as differential glycosylation, increase the variability of these proteins even more. For CGM8, PSG15, and allelic variants of PSG7 and PSG8, stop codons have been found in the $\mathrm{N}$-terminal domain exons and it is assumed that they represent either pseudogenes (CGM8, PSG15) or nontranslatable alleles (PSG7, PSG8).

\section{SIZE OF THE RODENT CEA GENE FAMILY}

Many investigations regarding the expression patterns of CEA-related molecules during fetal development and in normal adult tissues, as well as in in vivo functional studies, cannot be carried out in humans and necessitate the establishment of an animal model system. Rodents, especially mice, are an obvious choice for such studies as they are genetically well characterized. Introduction of CEA-gene-regulatory regions together with indicator genes into transgenic mice, or gene inactivation by homologous recombination, can be utilized for studying both the regulation of expression and function. After transfer of the human CEA gene, with its specific regulatory regions to ensure expression in induced colonic tumors, the eventual therapeutic effect of anti-human CEA monoclonal antibodies can be determined in vivo.

As a basis for the functional investigations as well as for studying the expression patterns during fetal development, rodent CEA-related genes first had to be isolated and characterized. This was achieved in both rat and mouse by using probes from human CEA gene family members (27-32). Other workers successfully isolated CEA-related genes (33), or proteins $(34,35)$, after first studying specific functions. The implications of these functions will be discussed in more detail below. Rodent CEA-related genes can also be divided into subgroups based on sequence comparisons. The present situation is shown in Table 2 which shows three subgroups.
TABLE 2. Classification of the Rodent CEA Gene Families

\begin{tabular}{ll} 
Old gene or clone name & $\begin{array}{c}\text { New gene or } \\
\text { mRNA name }\end{array}$ \\
\hline Subgroup 1 & \\
Mouse & mmCGM1 \\
mCEA1 (29), mmCGM1 (28) & mmCGM2 \\
mCEA2 (29), mmCGM2 (31) & mmCGM3 \\
mCEA3 (29) & mmCGM4 \\
mCEA4 (29) & \\
Rat & \\
ecto-ATPase (33), pp 120/HA4 (152), \\
$\quad$ C-CAM 105 (124) & ecto-ATPase \\
Subgroup 2 & \\
Mouse & mmCGM5 \\
mmCGM5 (32) & mmCGM6 \\
mmCGM6 (32) & mmCGM7 \\
mmCGM7 (32) & mmCGM9 \\
mmCGM9 (32) & \\
Rat & mCGM1 \\
rnCGM1 (27, 30) & mCGM3 \\
mCGM3 (27) & rn CGM4 \\
rnCGM4 (27) & \\
Subgroup 3 & \\
Mouse & \\
mmCGM8 (32) & \\
Rat & \\
rnCGM2 (27) & mmCGM8 \\
\hline
\end{tabular}

Within a subgroup, the genes reveal $80-90 \%$ sequence similarity at the nucleotide level, whereas between subgroups the similarity drops to $55-60 \%$. To date, maximally 12 rodent CEA-related genes have been described although some of these may represent splice variants of the same gene, e.g., mmCGM2 and mmCGM4 (Table 2 and 29).

If we compare sequences between the rodent and human CEA gene family members, it is impossible to determine individual counterparts. We find $50-60 \%$ sequence similarity, irrespective of the subgroups. A rapid sequence divergence of the CEA gene families is obvious between these two mammalian orders, and detailed, computer-assisted analyses indicate a parallel but independent evolution, which took place after mammalian divergence $(36,37)$. This complicates the application of an animal model, but expression patterns help to assign at least the subgroups.

\section{DOMAIN STRUCTURE IDENTIFIES CEA-RELATED MOLECULES AS MEMBERS OF THE IMMUNOGLOBULIN SUPERFAMILY}

Analysis of the deduced primary and secondary structures of the human and rodent CEA-related molecules have made it possible to define specific domains, which are common to the respective CEA gene families. However, differences in the domain combinations are found, especially for members of the second rodent subgroup (Table 2), compared to all human CEA-related molecules.

As can be seen in Figures 1 and 2, all CEA-related mole- 
CEA

\begin{tabular}{|c|c|c|c|c|c|c|c|}
\hline $\mathbf{L}$ & $\mathbf{N}$ & A 1 & B I & A 2 & B 2 & A 3 & B 3 \\
\hline 81 & & $c \quad c$ & c c & C $\mathrm{C}$ & C $\mathrm{C}$ & C C & C C \\
\hline
\end{tabular}

NCA

\begin{tabular}{|c|c|c|c|}
\hline $\mathbf{L}$ & $\mathbf{N}$ & A & $\mathbf{B}$ \\
\hline DEA & & $\begin{array}{ll}c & C\end{array}$ & c C \\
\hline
\end{tabular}

BGP a

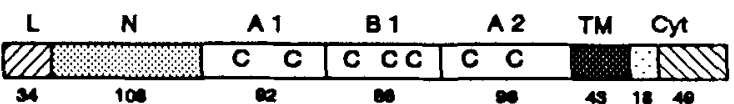

BGP 9

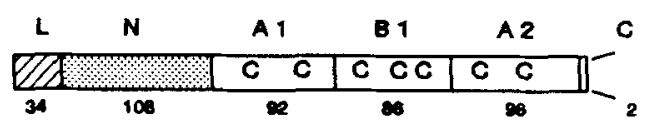

BAP e

L N

21

L $\mathrm{N}$

BGP

\begin{tabular}{|c|c|c|c|}
\hline $\mathbf{L}$ & $\mathbf{N}$ & A1 & B 1 \\
\hline 87 & & c c & $\mathrm{cec}$ \\
\hline 34 & 108 & 92 & 80 \\
\hline
\end{tabular}

BGP b

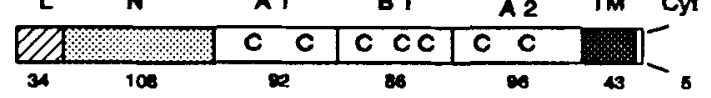

$\begin{array}{llllll}L & N & A_{1} & B_{1} & \mathrm{TM} & \mathrm{Cyt}\end{array}$

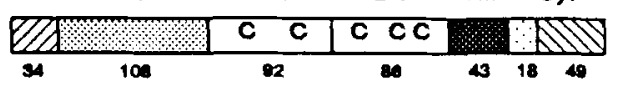

BGPI

\begin{tabular}{|c|c|c|c|c|c|}
\hline $\mathbf{L}$ & $\mathbf{N}$ & \multicolumn{2}{|c|}{ A 1} & B 1 & c \\
\hline ED & & C & C & c C C & \\
\hline 34 & 108 & & & 86 & 31 \\
\hline
\end{tabular}

Bapd

\begin{tabular}{|c|c|c|c|c|}
\hline $\mathbf{L}$ & $N$ & AI & B 1 & TM \\
\hline EDA & & c c & C CC & \\
\hline
\end{tabular}

$\operatorname{com} 1 \mathrm{a}$

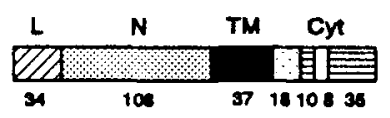

$\operatorname{cGM} 1 \mathrm{~b}$

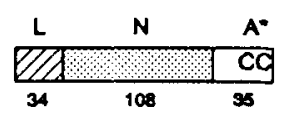

CGM 1C

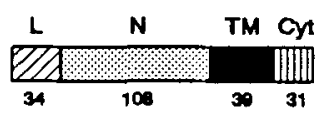

$\cos 7$

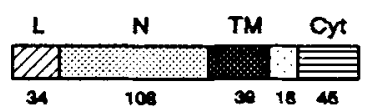

PSG Subgroup

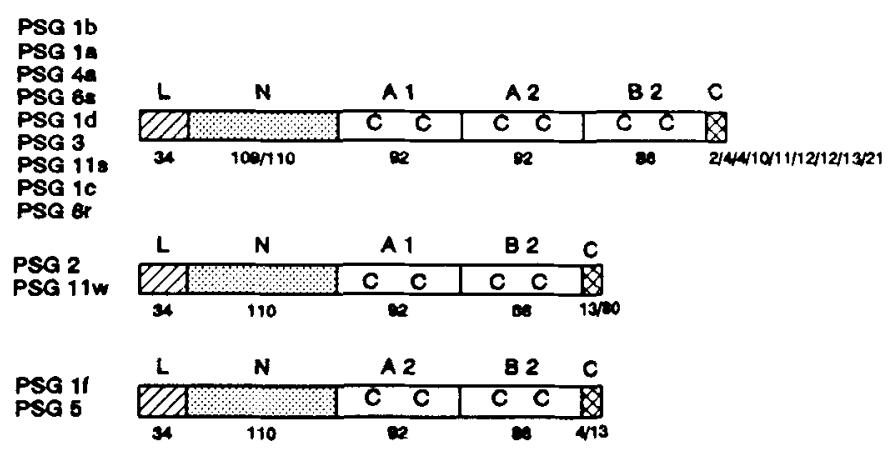

Fig. 1. Domain structures of human CEA-related proteins, based on deduced amino acid sequences. The proteins are listed in the two subgroups. (For original literature see Table 1.) Proteins encoded by splice variants of individual genes are differentiated by lowercase letters after the gene name. Different domains are indicated by letters above the blocks and different shading, whereby homologous regions have the same shading. $\mathrm{L}=$ leader peptide, $\mathrm{N}=\mathrm{N}$-terminal (IgV-like) domain, Al-A3 and B1-B3 = IgC-like domains, $\mathbf{M}=$ hydrophobic domain replaced by glycosyl phosphatidyl-inositol anchor,
$\mathrm{C}=\mathrm{C}$-terminal domain, $\mathrm{TM}=$ transmembrane domain, $\mathrm{Cyt}=$ cytoplasmic domain. Apart from the leader peptide, the domain borders are based on exon structures and do not necessarily correlate with functional regions (e.g., TM and Cyt domains). Amino acid numbers are presented below the blocks. The variability in length of the NCA and CGM6 M domains and the PSG C-terminal domains are listed. The positions of cysteines are indicated in the blocks $(\mathrm{C})$. 


\section{Subgroup 1}

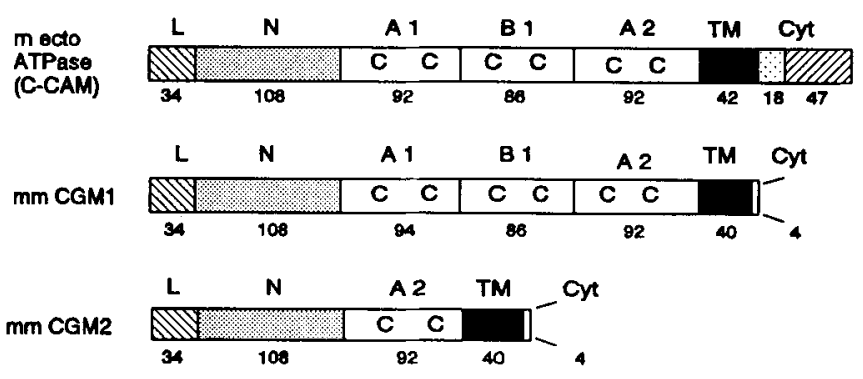

\section{Subgroup 2}

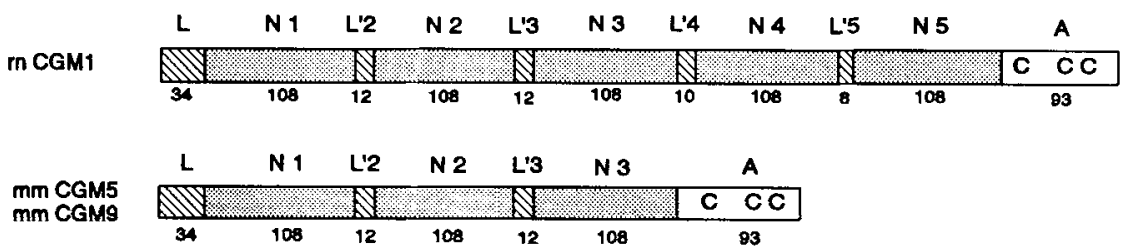

Fig. 2. Domain structures of the rodent CEA family based on deduced amino acid sequences. The proteins are listed according to their subgroups. (For original literature see Table 2.) Shading and labelling as for Figure 1.

cules have a leader (L) domain or signal peptide of 34 amino acids. This is necessary to direct the nascent proteins through the rough endoplasmic reticulum membrane for passage to the plasma membrane, where they either become anchored, as found for most of the human CEA subgroup and rodent subgroup 1 molecules, or they are secreted, as found for most members of the human PSG subgroup and rodent subgroup 2 . This leader peptide is cleaved off and is absent in the mature proteins. The main backbone of all CEA-related molecules is made up of a variable number of immunoglobulin-like domains, which places the CEA gene family within the immunoglobulin supergene family $(38,39)$. The human CEA-related molecules always contain one $\mathrm{N}$-terminal domain ( $\mathrm{N}$ domain) of 108-110 amino acid residues, whose derived secondary structure reveals homology to the immunoglobulin variable (IgV) domains. This is then followed by a different number of immunoglobulin constant-like (IgC) domains, consisting of 92 and 96 (A domains) or 86 amino acids (B domains). Each IgC-like domain contains at least two cysteine residues, which are assumed to stabilize the immunoglobulin-like fold via a disulphide bridge (40). Despite the absence of cysteine residues in the $\mathrm{N}$-terminal domains a similar fold is predicted, which could be stabilized by interactions between hydrophobic amino acids at the expected cysteine sites, as well as by a conserved salt bridge $(39,41,42)$. The number of IgC-like domains in human CEA-related molecules varies from none in CGM1a,c and CGM7 through two (e.g., NCA) or three (e.g., PSG1), to six in CEA (Fig. 1). Along with posttranslational modifications, such as differential glycosylation, this variability in the domain number accounts for the large size differences found for the protein products (cf. Tables 1 and $3 ; 11$ ).

As seen in Figure 2 the domain organization for members of the rodent subgroup 1, i.e., for mmCGM1 (29), mmCGM2 (31), and the rat ecto-ATPase (33), is similar to splice variants of BGP $(43,44)$, which belongs to the human CEA subgroup (Fig. 1). However, the members of the second rodent subgroup, i.e., mCGM1 (30), mmCGM5, and mmCGM9 (32) show a very different combination of immunoglobulinlike domains compared to human CEA family members. In this case, three (mmCGM5, mmCGM9) and five (rnCGM1) IgV-like $\mathrm{N}$ domains, of similar lengths to their human counterparts, are followed by a single IgC-like A domain (Fig. 2). Due to the exon structure, which will be discussed below, the internal $\mathrm{N}$ domains are separated by sequences normally found in the leader (L) domains. This very different combination of immunoglobulin-like domains makes it impossible to identify the corresponding human subgroup based on structural studies alone.

Most members of the human CEA subgroup as well as those belonging to the first rodent subgroup are apparently membrane-bound. In some cases, their derived amino acid sequences indicate that they are integral membrane proteins, i.e., BGPa,b,c, and d (43,44), CGM1a and c (45 and results 
TABLE 3. Assignment of CEA-Related Genes to Known Antigens: Current Status

\begin{tabular}{|c|c|c|c|c|c|c|c|}
\hline Gene & Antigen & $\mathbf{M}_{\mathbf{r}}(\times 1,000)$ & $\begin{array}{c}\mathrm{M}_{\mathrm{r}}(\times 1000) \\
\text { deglyc. }\end{array}$ & $\begin{array}{l}\mathbf{M}_{\mathrm{r}} \text { unglyc. } \\
\text { predicted }^{\mathrm{a}}\end{array}$ & $\begin{array}{l}\text { Membrane } \\
\text { anchorage }\end{array}$ & Methods applied for assignment & Evaluation \\
\hline \multirow[t]{5}{*}{ CEA } & CEA-180 (3) & 180 & $78^{\mathrm{b}}(224)$ & 72.3 & GPI $(38,46,49)$ & Amino acid sequences (38) & Confirmed \\
\hline & NFA 1(170) & $20-30$ & $?$ & - & $?$ & Amino acid sequence $(170)$ & Probable \\
\hline & $160 \mathrm{kDa}$ antigen $(225)$ & & & & & & \\
\hline & $(\mathrm{NCA}-2)(226)$ & 165 & $?$ & - & $?$ & Amino acid sequence (225) & Probable \\
\hline & MA-100 (227) & 100 & $?$ & - & $?$ & Amino acid sequence $(225)$ & Probable \\
\hline \multirow[t]{3}{*}{$\mathrm{NCA}$} & NCA-50 (21) & $45-60$ & $35^{\mathrm{c}}(50,110)$ & 33.9 & GPI $(50,52,110)$ & $\begin{array}{l}\text { Amino acid sequences, expression } \\
\text { of cDNA and immunological } \\
\text { assignment by mAb }(50,110)\end{array}$ & Confirmed \\
\hline & NCA-90 (228) & 90 & $35^{\mathrm{c}}(51)$ & 33.9 & GPI (51) & $\begin{array}{l}\text { N-terminal amino acid sequence, } \\
\mathbf{M}_{\mathrm{r}} \text { after deglycosylation, } \\
\text { peptide map (51) }\end{array}$ & Probable \\
\hline & TEX $(110)$ & 75 & $35^{\mathrm{c}}(110)$ & 33.9 & GPI (110) & Amino acid sequences (110) & Confirmed \\
\hline BGP & BGPI (229) & 90 & $?$ & $\begin{array}{l}\text { Different } \\
\text { splice } \\
\text { variants }\end{array}$ & $\begin{array}{l}\text { Presumably trans- } \\
\text { membrane (17) or } \\
\text { secreted (see Fig. 1) }\end{array}$ & Amino acid sequences $(43)$ & Confirmed \\
\hline CGM6 & NCA-95 (115) & 95 & $42^{\mathrm{C}}(50)$ & 33.9 & GPI (54) & $\begin{array}{l}\text { Expression of cDNA and } \\
\text { immunological assignment with } \\
\text { mAbs, tissue distribution (54) }\end{array}$ & Probable \\
\hline$?$ & CEA-160 (230) & 160 & $64^{\circ}(231)$ & & $?$ & & \\
\hline$?$ & NCA-26 (232) & 26 & $14^{\mathrm{d}}(45)$ & & $\begin{array}{l}\text { Membrane, not PI- } \\
\text { PLC sensitive (232) }\end{array}$ & & \\
\hline$?$ & NCA-58 (233) & 58 & $41^{b}(233)$ & & Secretory (233) & & \\
\hline$?$ & NCA-80 (233) & 80 & $69^{\mathrm{b}}(233)$ & & Secretory (233) & & \\
\hline ? & NCA-90 (232) & 90 & $28^{d}(232)$ & & GPI (232) & & \\
\hline$?$ & NCA-95 (232) & 95 & $45^{d}(232)$ & & GPI (232) & & \\
\hline$?$ & NCA-140 (234) & 140 & $70^{d}(234)$ & & $\begin{array}{l}\text { Membrane, not PI- } \\
\text { PLC sensitive (234) }\end{array}$ & & \\
\hline$?$ & NCA-160 $(228,232)$ & 160 & $\begin{array}{l}90^{d}(228) \\
65^{d}(232) \\
\end{array}$ & & $\begin{array}{l}\text { Membrane, not PI- } \\
\text { PLC sensitive (232) }\end{array}$ & & \\
\hline
\end{tabular}

aDependent on the deglycosylation method different $\mathrm{M}_{\mathrm{r}}$ can be predicted.

betermined after tunicamycin treatment, no N-linked carbohydrates, GPI-moiety present.

'Trifluoromethansulfonic acid treatment, terminal Asp-linked GlcNAc present, GPI-moiety partially removed.

${ }^{\mathrm{d}}$ Endoglycosidase $\mathrm{F}$ treatment, $\mathrm{M}_{\mathrm{r}}$ determined as in ${ }^{\mathrm{a}}$.

to be published), CGM7 (45), mmCGM1 and $2(29,31)$, and rat ecto-ATPase (33). In these proteins, a hydrophobic transmembrane (TM) domain is predicted to follow the last immunoglobulin-like domain, and this in turn is succeeded by a cytoplasmic domain (Cyt), whose length can vary (Figs. 1, 2). Alternatively, some human CEA-subgroup members have been shown to be anchored after post-translational modification and replacement of the hydrophobic membrane (M) domain (Fig. 1), with a glycosyl phosphatidylinositol moiety, e.g., CEA (46-49), NCA (50-52), and the presumed product of the CGM6 gene, NCA-95 $(53,54)$. Four members of the CEA subgroup (CGM1b, BGPg,h,i) apparently represent secreted proteins, as they lack a hydrophobic C-terminal domain. However, corresponding proteins must first be identified before this can be confirmed.

The majority of the human PSG subgroup members have very short, mainly hydrophilic, C-terminal domains consisting of two to 21 amino acids and the rodent subgroup 2 members (rnCGM1, mmCGM5, mmCGM9) completely lack C domains. This indicates that these proteins are directly secreted from the cells and, indeed, in experiments where human PSG
cDNA clones have been transfected into eukaryotic cells, the products appear quickly in the supernatant (55-57). One possible exception has been described by Zheng et al. (58) for PSG11w (Fig. 1), which was isolated from a placental cDNA library. This cDNA species apparently encodes a PSG protein with a long hydrophobic C-terminal region of 80 amino acids, which could well be used for membrane anchorage. Alternatively, this clone may merely represent an incompletely spliced mRNA product, because on comparison with PSG genomic sequences (59-61), it is clear that the intron following the B2 exon is still present in this particular cDNA clone and that the hydrophobic $\mathrm{C}$-region is encoded by these intron sequences. Polyadenylation was, however, found in this clone, but unequivocal proof that it encodes a membrane-bound PSG can only come through identification of the corresponding protein, e.g., in the placenta.

\section{CHROMOSOMAL LOCALIZATION OF THE HUMAN AND MOUSE CEA GENE FAMILIES}

Two different approaches have allowed the chromosomal localization of the human CEA gene family. One approach 
utilized human/rodent hybrid cell analyses (62-64), whereas the second approach was to hybridize human metaphase chromosome spreads with tritium-labelled DNA probes $(61,65-$ 68). These experiments have shown that the CEA and PSG subgroup genes are clustered on the long arm of chromosome 19 in the region 19q13.1-19q13.3. Using somatic cell hybrids, Schonk et al. (64) reported that the CEA gene family is located on the distal portion of $19 \mathrm{q} 13.1$, close to the genes encoding hormone-sensitive lipase (LIPE), transforming growth factor (TGF)- $\beta 1$, and cytochrome $\mathrm{P}_{450}$ subfamily IIA (CYP2A). In one report we provided evidence that CEA-related genes may also be located on the short arm (19p13.2-19p13.3) of chromosome 19 (65). However, the hybridization signal seen was only found by using a genomic probe containing the A and the start of the B domain exons from the NCA gene, including intron sequences. As a corresponding signal was not visible using a CEA cDNA fragment containing $\mathrm{A}$ and $\mathrm{B}$ domains, we assume that this was probably due to crosshybridization with intron sequences and that all CEA-related genes are indeed located on the long arm of chromosome 19.

We have analysed this region more closely by using pulsefield gel electrophoresis in order to separate large DNA fragments resulting from digestion with rare-cutting restriction endonucleases. After transfer to charged nylon membranes, the digested DNA was hybridized with gene-specific probes in an attempt to determine putative linkage of CEA-related genes. Together with single and double digestions, it was possible to construct a long-range restriction map of this region. With the help of chromosome walking studies, fine restriction endonuclease mapping has also been carried out for some regions. These results have been confirmed by $\mathrm{H}$. Mohrenweiser and collaborators at the Lawrence Livermore National Laboratory, USA. This group has constructed a cosmid library from chromosome 19 and with the help of fingerprinting, overlap detection algorithms, and chromosome walking, they have been able to identify a large number of overlapping cosmid clones from the CEA gene family region through hybridization with a conserved sequence from a CEA cDNA clone. In parallel, the same group has carried out high-resolution in situ mapping by using gene-specific probes on interphase chromosomes. These and our results indicate that the whole CEA gene family apparently extends over a $1.2 \mathrm{Mb}$ region at
$19 q 13.1$. Where determined, individual genes are very closely linked, being separated by $16 \mathrm{~kb}$ (CEA subgroup genes; to be published), or $6 \mathrm{~kb}$ (PSG genes; 61,69). The PSG genes have been mapped telomeric of the CEA subgroup by analysis of somatic cell hybrids (T. Willcocks, personal communication). A schematic map of the CEA gene family region, including the gene order and orientation as far as it is known, is shown in Figure 3.

Using a probe from a mouse CEA-related gene (mmCGM8) belonging to rodent subgroup 3 (Table 2) to analyse a panel of interspecific backcross mice, this gene has been located at mouse chromosome 7 (A. Saunders and M. F. Seldin, personal communication). This region is syntenic to human chromosome 19; i.e., the counterparts of a number of genes located at human chromosome 19 are found to be similarly linked on mouse chromosome 7 (70).

\section{GENOMIC ORGANIZATION OF CEA-RELATED GENES}

Analysis of the genes encoding CEA and related molecules in humans $(42,59-61,69,71-74)$ and in rodents $(27,30,32)$ has revealed a close correlation between the domains and the exon regions. This is shown in Figure 4 for the CEA gene. Such a correlation is also a typical feature for other members of the immunoglobulin supergene family (40). A closer analysis of the derived amino acid sequences in the CEA gene shows that the immunoglobulin-like domains, which contain highly ordered $\beta$-sheets, are always surrounded by prolinerich regions located close to the exon borders (71). These regions disrupt ordered structures, thus marking the boundaries between adjacent domains.

In rodents and humans, the first exon encodes the $5^{\prime}$-untranslated region and the first two-thirds of the leader peptide. The second exon encodes the rest of the leader and the complete $\mathrm{N}$-terminal domain. In rodent subgroup 2 (Table 2 ), this exon is repeated up to five times, as found in mCGM1 (30 and Fig. 2). Following the $\mathrm{N}$-terminal domain exon is a variable number of IgC-like ( $\mathrm{A}$ and $\mathrm{B}$ ) domain exons, ranging from one in mmCGM5 (32) to six in CEA (Fig. 4). Beyond these exons, variability is found in the number and structure of the exons encoding the M, TM, and Cyt or C-terminal

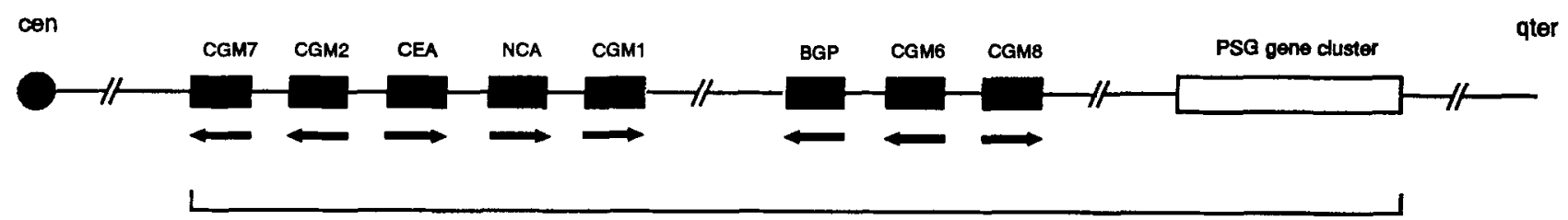

approx. $1.2 \mathrm{Mb}$

Fig. 3. Schematic map of the CEA gene family region on the long arm of chromosome 19. The genes are shown as filled-in (CEA subgroup) or an open (PSG subgroup) block. The direction of transcription is indicated by arrows. cen $=$ centromere, qter $=$ telomeric end of chromosomal long arm. 


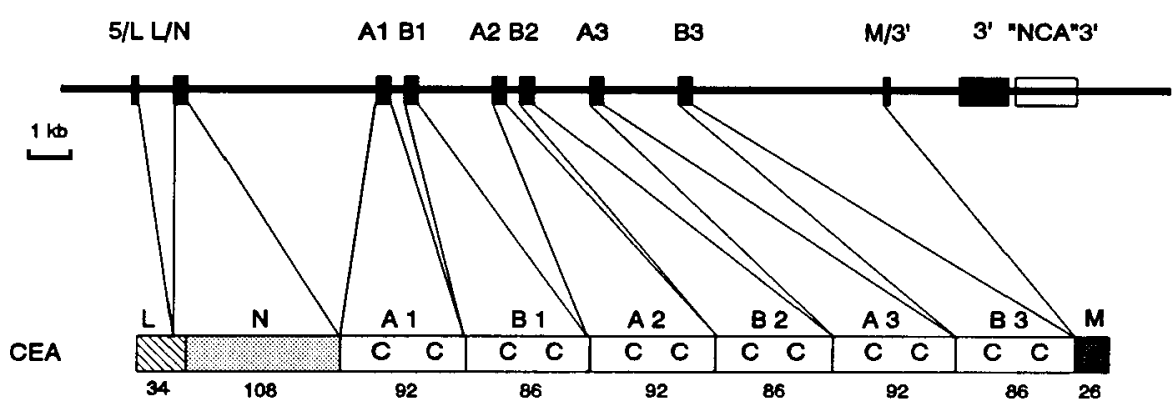

Fig. 4. Correlation of exon and domain structures for the CEA gene. The genomic structure of the CEA gene is shown in the upper part of the figure as published elsewhere (71), and the lower part of the figure shows the domain structure (cf. Fig. 1). The exon names are the same as the domains, or are discussed in the text.

domains and the $3^{\prime}$-untranslated regions (cf. Fig. 1). A detailed analysis of the organization and the many splice variants found for the human CEA gene family in this $3^{\prime}$-region was recently reported by Zimmermann et al. (57) and will not be further discussed here. It is of interest to note that the otherwise highly similar PSG subgroup genes show variability in this region. Indeed, this variability can be used to identify various classes within the human PSG subgroup, whereby proteins with similar C-terminal domains can be classified together (Fig. 5). So far, little is known about the genomic organization of the C-terminal and $3^{\prime}$-untranslated regions of the rodent CEA gene family.

Not all of the putative exons found through human genomic analyses are present in corresponding cDNA clones. For example, the genes encoding PSG4 and PSG5 $(60,61)$ both have four internal exons, each of which contains an IgC-like (A1, B1, A2, B2) domain, cDNA clones have been characterized for the PSG4 gene, which lack the B1 domain $(57,75)$, and PSG5 cDNA clones have been described which lack both the $\mathrm{A} 1$ and $\mathrm{B} 1$ domains $(55,60)$. The splice sites for the miss- ing exons do not appear to be mutated when compared to splice consensus sequences (76), but in both genes it is interesting to note that the $\mathrm{B} 1$ exons contain a stop codon $(60,61)$. The A1 exon in the PSG5 gene, on the other hand, contains an open reading frame, so that potentially, protein products including this domain could also exist. A similar situation for exon deletion was described by Oikawa et al. in PSG8 (59, Table 1), where a mutated donor splice site for the B1 exon was found. It is interesting that no PSG cDNA clone so far analysed has been shown to contain a Bl exon (Fig. 1), although the reasons for this are unknown.

Exon deletion has also been found for members of the CEA subgroup; e.g., differential splice variants have been described for BGP (44, see Fig. 1). The A1 exon of CGM1 apparently contains a stop codon, which would lead to premature termination of translation from transcripts containing this domain, e.g., CGM1b (Fig. 1). Interestingly, two other splice variants (CGMla,c) do not contain this exon, whereby readthrough can be achieved (45). One of the criteria used to distinguish the CEA and NCA transcripts has been through

Subclass 1

\section{P8g1a \\ PQG4a \\ PGG7a \\ P8G8a}

Subclass 2

PEG2

PBG3

Subclass 3

P8G6r

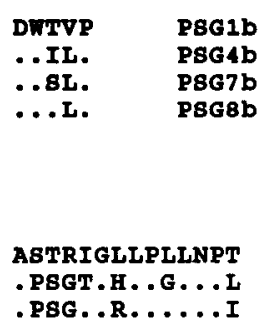

.PSGT.H..G...L

$\begin{array}{ll}\text { EAL } & \text { PSG1C } \\ --- & \text { PSG4C } \\ .8 . & \text { PSG7C } \\ . . & \text { PSG8C }\end{array}$
GKMIPABLAIGF

i.

.

Fig. 5. Subgroups of the human PSG family based on sequence similarity of their deduced C-terminal domains (cf. Fig. 1). Amino acid sequences are shown in the single-letter code, whereby homologous regions are grouped together. Dots indicate identical amino acids and dashes unknown sequences in comparison with the first-listed C-terminal domain in each subclass. For PSG4, splice variants $4 \mathrm{~b}, 4 \mathrm{c}$, and $4 \mathrm{~d}$ have not yet been found, but are predicted. The original literature is listed in Table 1. 
hybridization of probes from their 3 '-untranslated regions (65), where they differ completely. However, analysis of the CEA gene (71) reveals that this is due to differential splicing and that a putative exon with an NCA-like 3 '-untranslated region also exists, with an apparently intact splice acceptor site. Although no CEA transcript with an NCA-like 3 '-untranslated region has been described so far, its existence cannot be ruled out. Furthermore, it may be expected that similar sets of 3 '-untranslated region exons might also exist in other CEArelated genes.

It is interesting to note the presence of Alu-like repetitive elements in the homologous $3^{\prime}$-untranslated regions of the CGM6 and CEA mRNAs $(53,59)$. About 300,000 Aluelements are present in the human genome, mainly in introns and intergenic regions (77). In the mature CEA mRNA two Alu sequences are found and in CGM6 mRNA one is present. As the Alu elements are located at different sites in the two mRNAs, independent insertion of these mobile elements must have occurred after separation of the two genes during evolution. Using the polymerase chain reaction (PCR), we could detect the presence of the first Alu-element in the CEA mRNAs of two primates, i.e., chimpanzee and African green monkey, suggesting the insertion of this element before primate speciation. At the genomic level, at least six Alu-elements have been found in a $7.5 \mathrm{~kb}$ section of the $3^{\prime}$-untranslated region of the CEA gene, which is an exceptionally high concentration, although the relevance is still unknown $(71,72)$.

Other interesting repetitive elements composed of simple DNA sequences have also been found in various non-coding regions of CEA-related genes. For example, a poly (dC-dA) sequence of varying length has been found in the first intron of all human CEA-related genes $(42,72-74)$. In the PSG subgroup this is followed by a poly $(\mathrm{dG}-\mathrm{dT})$ sequence and in rat group 2 genes homopurine/homopyrimidine stretches with $\mathrm{d}(\mathrm{CCTT})$ and d(GGA) units are found at similar positions (27). More recently, we have found similar repetitive simple sequences located approximately 180 nucleotides upstream of the transcriptional initiation sites of two human PSG genes and the CGM6 gene (A.-M. Eades-Perner, personal communication). The relevance of these simple sequences remains to be determined, although it is known that they can form Z-DNA (78). Such sequences may play a role in the regulation of gene expression and, indeed, correlate with DNase I hypersensitive sites in the 5 -region of the human $\beta$-like-globin gene domain, where they are located close to a number of enhancer elements (79). They have been shown to be important for regulating expression of the $\beta$-globin gene (80). In the rat growth hormone gene promoter region, repetitive simple sequences exist which could also play a role in regulating gene expression there (81). It is thought that these elements, in their open conformation, may allow easy access for factors involved in control of transcription. Alternatively, simple sequences could play a role in recombination events $(82,83)$, or gene rearrangement $(84)$.

\section{EXPRESSION PATTERNS OF CEA-RELATED GENES IN HUMANS}

Before the in vivo function of CEA-related molecules can be properly investigated, it is important to determine where the individual molecules are expressed. The CEA family shows great variability in the expression patterns of individual members, as defined by immunological methods (11). NCA reveals a broader expression spectrum than CEA and is found not only in tumors but also in a variety of normal fetal and adult tissues such as colonic mucosa, lung, spleen, liver, etc., as well as in polymorphonuclear granulocytes, macrophages, and monocytes $(85,86)$. BGP1, on the other hand, was discovered in the epithelium of bile canaliculi (23). PSG are expressed in increasing amounts by the placenta during pregnancy, from which they are secreted into the maternal bloodstream. At term they represent the major placental protein, with concentrations of up to $400 \mu \mathrm{g} / \mathrm{ml}$ serum (87). One major drawback of the immunological approach for determination of expression is that it is difficult to determine the specificity of the antibodies used, as cross-reactivity can only be ruled out when all the antigens have been isolated and fully characterized. Another problem is that the identification of a given antigen in a specific tissue or organ does not necessarily mean that this molecule is actually produced there. For example, these molecules could be secondarily bound or engulfed by phago- or pinocytosis, e.g., as found for Kupffer cells in the liver, where a receptor-mediated endocytosis of CEA has been reported $(88,89)$.

With the help of molecular cloning of CEA-related cDNAs into expression vectors, followed by subsequent transfection into eukaryotic cells, the specificity of polyclonal and monoclonal antibodies can be determined against individual products. Stable transfectant clones already exist which express CEA $(52,90,91$, and to be published), NCA-50/90 (51,52, 90,92), NCA-95 $(54,45)$, BGPa and b $(93,94)$, CGMla (G. Nagel, personal communication), PSG1 a (55,57), PSGld and PSG5n (55), and PSG3 and PSG6r (to be published). This panel of transfectants is continuously being expanded; however, even a complete panel cannot ensure that all naturally occurring epitopes will be contained therein. For example, differential glycosylation and proteolysis, as found in vivo, give rise to additional products, whereby modified or new epitopes could be generated.

Through the specific determination of mRNA species encoded by an individual gene, the problem encountered by immunochemical investigations at the protein level can be circumvented. Sequence comparisons of all known CEArelated genes make it easier to design specific DNA or RNA probes for differentiation of individual mRNAs than to develop specific antibodies against corresponding proteins. Various methods are available for identification of these mRNA species. One approach is to extract RNA from different organs, followed by electrophoretic size fractionation, transfer to nylon 
membranes, and hybridization with gene-specific radiolabelled DNA probes (Northern analysis). Alternatively, mRNA can be converted to DNA and amplified by using gene-specific oligonucleotides in PCR, which has the advantage of simplicity and high sensitivity. A third possibility is to carry out in situ hybridization on tissue sections, whereby the actual cells expressing individual CEA-related transcripts can be identified.

Many studies to determine expression of CEA-related genes at the transcriptional level have applied the Northern blot technique $(10,44,54,57,58,61,65,95-107)$. Using this approach, and with the help of gene-specific or subgroup-specific DNA probes, a number of mRNA species varying in size have been identified in different tumors and some normal tissues. For some genes, more than one transcript exists, representing either mRNA species with different polyadenylation sites (e.g., CEAa,b, BGPe,f, PSG1d,e) or splice variants of individual genes (e.g., BGPa-i, PSG1a-d), as found by cDNA cloning. In some cases, different genes or splice variants of the same genes encode transcripts of similar sizes (e.g., PSGla and PSG4a), which makes it difficult to identify CEA-related mRNA species by size alone. Furthermore, for the highly conserved PSG subgroup (Table 1), it is only possible to differentiate individual transcripts by using oligonucleotide probes, which have limited sensitivity in Northern blot analyses. Therefore, this method cannot be used to screen for lowcopy-number mRNAs.

An alternative approach with much higher sensitivity is PCR. Once sequences for individual genes or their mRNAs and splice variants are available, specific oligonucleotide primers can be synthesized for conversion of putative transcripts into cDNA and subsequent amplification of DNA fragments. This approach has a number of benefits over the Northern technique, due to its high sensitivity. This allows investigations on biopsy material to be carried out, which normally would not provide enough RNA for Northern blot hybridization. We have established a PCR assay system for differentiation of CEA, NCA, CGM6, BGP, and PSG subgroup transcripts. The specificity of each set of of primers has been tested against individual cDNA clones and we are currently analysing large numbers of tumors and normal tissues for transcripts of the different genes. We are now able to determine the mRNAs of individual genes with $500 \times$ less total RNA than with conventional Northern blot analyses. Furthermore, in some tissues, where we gained negative results with the latter method, PCR has unequivocally identified transcripts for some CEA-related genes.

Both Northern blot and PCR analyses only allow determination of transcripts in tissue extracts, but do not allow discrimination of the individual active cells. This type of analysis can best be carried out by in situ hybridization on tissue sections. This method has already been adopted to determine which cells transcribe the CEA and NCA genes in cell culture as well as in a number of colorectal adenomas and carci- nomas (98). The authors report positivity in $7 / 15$ adenomas and 13/15 adenocarcinomas with the CEA probe. With the NCA probe, $6 / 15$ adenomas and $10 / 15$ adenocarcinomas were positive. The intensity of the signal appeared to be stronger in adenocarcinomas than in adenomas. In general, NCA and CEA transcripts were coexpressed and showed a very similar localization in positive cells. In a comparison with Northern blot analyses it was found that the in situ applied method was less sensitive and in some of the tissues which were apparently negative, Northern blot studies identified both CEA and NCA transcripts. Similar results were reported by Monde et al. (108).

Taking all these analyses together, distinct expression patterns are becoming apparent for individual CEA-related mRNAs. In general, NCA and CEA appear to be coexpressed in a variety of adenocarcinomas or derived cell lines and adenomas $(10,65,97,101,105)$. Although the CEA levels are much lower in corresponding normal tissues, e.g., in normal colonic mucosa as compared to colorectal adenocarcinomas, CEA transcripts are found in comparably high amounts (100). In contrast, the steady-state levels of NCA transcripts are normally very low in normal intestine compared to much higher levels in colonic carcinomas, as reported by a number of groups $(10,97,101,109)$. In parallel, we have also found higher NCA antigen levels in the sera of colonic tumor patients. These results indicate that NCA may also be a useful marker for colonic tumors.

NCA transcripts, but not CEA transcripts, have been found at very low levels in peripheral leukocyte preparations (45) and at much higher levels in bone marrow extracts or leukocytes from chronic myeloid leukemia (CML) patients. Transcripts from the CGM6 gene have also been discovered in these leukocyte preparations, but nowhere else to date (54). For the NCA and CGM6 genes, the corresponding antigens are NCA-50/90 or TEX $(50,51,110)$ and probably NCA-95 (54), respectively. We have found these antigens mainly in neutrophilic, to a lower extent in eosinophilic, but not in basophilic granulocytes, and judging by the steady-state levels of their transcripts, the genes are apparently active in immature but inactive in mature granulocytes (54). Therefore, these mRNAs may be useful as markers for granulocyte differentiation. Recently, through investigations using monoclonal antibodies, some members of the CEA gene family or epitopes thereof have been correlated with surface markers from the $\mathrm{CD}$ series. Watt et al. (111) have recently shown that the neutrophil-specific cluster of differentiation, $\operatorname{CD66}(112,113)$, is present on members of the CEA family, and CD67 represents a cluster which probably corresponds to NCA-95 (114 and to be published). Immunological studies have revealed the presence of NCA-95 in macrophages and monocytes (115). Corresponding transcripts have, however, so far not been found in these cells (116), indicating that NCA-95 is phagocytosed, but not expressed there. In support of this are recent data from Novak-Hofer et al. (117), who investigated the binding activ- 
ities of monoclonal antibody 47 (115), which recognizes NCA-95 on a promyelocytic cell line (HL-60). Dimethylsulfoxide (DMSO) induces these cells to differentiate into neutrophils, whereby the Mab 47 binding increased up to fourfold 7 days after treatment. In contrast, phorbol-12-myristate13-acetate (PMA), which induces differentiation of HL-60 cells into monocyte/macrophages, led to a decrease in binding. These results suggest that NCA-95 is expressed at a low level in promyelocytes and is up-regulated during neutrophilic, but is switched off during monocytic, differentiation.

PSG transcripts have mainly been found in placenta, where they are apparently coexpressed $(61,102)$. PSG cDNA clones have also been found in libraries from a number of other tissues, such as testis (118), fetal liver (55-57), salivary gland (119), HeLa cells (75), two myeloid cell lines-HL60 (60) and KGl (103) - and the spleen of a CML patient (G. Nagel, personal communication). These results indicate that PSG are not, as the name would suggest, pregnancy specific, but it remains to be determined whether PSG proteins have a function in these tissues. In most of the above-mentioned studies, the existence of PSG is based solely on the isolation of cDNA clones from the RNAs of different tissues. However, this yields no information on the absolute amounts of the corresponding PSG mRNAs, which in extreme cases, may only be present as single copies in the RNA preparations. At the protein level, PSG are synthesized by placental and normal fibroblast cell lines $(120,121)$. In some instances, differential expression of individual PSG species has been reported, e.g., PSG6 transcripts are either absent or not very prevalent in normal placenta $(61,69)$, whereas their concentration in hydatidiform mole, a benign tumor of trophoblastic origin, is very high (69). Similarly, variability in the mRNA steadystate levels of other PSG genes may relate to pathological pregnancies (102).

Taken together, the RNA analyses (not including identification of cDNA clones) indicate a relatively narrow range of expression for individual members of the human CEA gene family, although more determinations remain to be carried out before distinct patterns can be defined.

\section{IDENTIFICATION OF HUMAN/RODENT COUNTERPARTS BY COMPARING EXPRESSION PATTERNS}

Expression patterns have been compared in an attempt to identify rodent counterparts to human CEA-related genes. Although anti-human CEA (28) and PSG antisera (122) were shown to cross-react with CEA/PSG-related antigens in rodents, a specific assignment of counterparts could not be made due to the lack of specificity of the antisera for individual molecules. Investigations have also been carried out at the transcriptional level by using Northern blot analyses $(27,28,30)$ and in situ hybridization studies $(123)$.

Transcripts encoded by members of the rodent CEA gene family subgroup 1 (Table 2) have been identified by cDNA cloning as present in mouse colon $(28,31)$. Utilizing probes from mmCGM1 and mmCGM2 for Northern blot analyses under low-stringency conditions, transcripts of different sizes have been identified in mouse colon, liver, and uterus $(28,31)$, an expression pattern which is similar to that for the human CEA subgroup. Huang et al. (123) have made detailed expression studies in developing mouse embryos with the same probes. Northern blot studies allowed identification of transcripts in fetal colonic and intestinal tissues, while in situ hybridization investigations carried out at low stringency also revealed expression of rodent CEA-related genes in cartilage and bone, meninges, muscle layers of the stomach and intestine, blood vessel walls, bronchioles, and dermis at various stages of mouse embryonic development. These tissues are all derived from mesenchyme and the authors speculate that CEA-related molecules may play an important role during active morphogenesis. The implications of these findings regarding function will be discussed in more detail below, but the benefits of an animal model for such studies are obvious.

The expression pattern of rodent subgroup 2 (Table 2) has also been investigated at the transcriptional level. Northern blot analyses using gene-specific probes from mCGM1 under high-stringency conditions have revealed mCGM1 transcripts only in rat placenta, but not in other tissues or organs $(27,30$, and to be published). We have similar results for expression of mmCGM5 in mouse placenta (32). These results have been confirmed by in situ hybridization investigations, whereby we have been able to localize rnCGM1 transcripts to the spongiotrophoblast and some giant trophoblast cells. In addition, we find some labelling in the connective tissue surrounding the ducts of adult salivary glands, which correlates with the presence of PSG transcripts in human salivary glands (119). Taken together, these data strongly indicate that the rodent subgroup 2 genes (Table 2) encode the PSG counterparts.

Antibodies raised against rodent CEA-related proteins have been used for the localization of these molecules. Recently, Aurivillius et al. (124) showed that the cell adhesion molecule C-CAM (125) represents the same molecule as the rat ectoATPase described by Lin and Guidotti (33). C-CAM was originally identified by using antisera in hepatocytes (35), where strongest antibody staining has located it at the membranes of bile canaliculi in mature liver (126). C-CAM has also been found at relatively high concentrations on the brush border of epithelial cells in the mucosa of the small intestine and proximal renal tubules, as well as intracellularly in megakaryocytes, platelets, and polymorphonuclear leukocytes (126, 127). This expression pattern is as expected for counterparts to the human CEA subgroup, and the derived domain structures of the proteins (Fig. 2) support this. These results, together with the variable molecular weights found for C-CAM isolated from different tissues (125), indicate that the antisera used cross-react with different members of the rat CEA subgroup. 
For analysis of the proteins encoded by rodent CEA subgroup 2 genes (Table 2), antisera have recently been developed in our laboratory against a synthetic peptide from the derived $\mathrm{C}$-terminal region of the rnCGMl product and against the first IgV-like domain. Both antisera recognize a polypeptide with a relative molecular mass $\left(M_{r}\right)$ of $120,000-130,000$ in the supernatant of rnCGM1 transfectants, which is of the size expected from the derived amino acid sequence data $\left(M_{r}\right.$ 75,000 ) and a calculated $M_{r}$ of 47,000 for the deduced carbohydrate moiety. Independent studies by Ogilvie et al. (122) reported on the cross-reactivity of antisera raised against human PSG with a major glycoprotein of a similar size $\left(M_{r} 120,000\right)$, which is present in the basal zone tissue (spongiotrophoblast) of rat placenta. These results have been repeated in our laboratory and it could be confirmed that the proteins are identical in size. Furthermore, first investigations on the cytochemical localization of this protein during placental development indicate an exact correlation of its expression pattern with that of rnCGM1 transcripts. Using our anti-rnCGM1 antisera, this protein has been identified in the blood of pregnant female rats, but not in blood from non-pregnant females. Taken together, these data confirm that the rodent subgroup 2 genes are the counterparts of the human PSG subgroup.

So far, the rodent subgroup 3 genes have only been partially characterized at the sequence level and little is known about their expression patterns. Indeed, the existence of a third subgroup is only based on sequence comparisons, because the genes therein cannot be assigned to one of the other subgroups. It may be assumed that rnCGM2 and mmCGM8 are homologues due to their high sequence similarities (93\% at the nucleotide level in the N1 domain exons).

\section{IDENTIFICATION OF THE ANTIGENS ENCODED BY HUMAN CEA-RELATED GENES}

Although there is evidence that most of the CEA and PSG genes are now characterized, identification of the corresponding antigens still remains a major problem. The present knowledge regarding such correlations is summarized in Table 3. Certainty prevails only in those cases where the antigen has been purified and enough protein sequence data exists to allow such correlations (i.e., for CEA $180, \mathrm{NCA}-50 / 90$, or TEX and to a limited extent BGP). Although many CEA-related genes have been identified, it still cannot be ruled out that additional ones exist and also, a number of molecules described as CEA-related probably represent CEA degradation products, as indicated by amino acid sequencing, e.g., NFA-1, NCA-2, and MA-100 (Table 3).

An alternative approach for identification is to determine the reactivity pattern of different, well-characterized monoclonal antibodies with the proteins synthesized by transfectants of individual CEA-related CDNAs and to relate this to their reactivity pattern to known antigens. Using this method, evidence would suggest that the CGM6 gene encodes NCA-95
(54), although there is a slight discrepancy between the calculated and experimentally found molecular weights of the polypeptide moiety, which suggests that more than NCA-95 could exist (Table 3 ). Due to the high sequence similarity of CEA-related proteins and the limited number of accessible natural epitopes, it may be expected that it is not possible to obtain monoclonal antibodies raised against protein extracts which are specific for each antigen. By comparing amino acid sequences derived from molecular cloning analyses, regions specific to individual antigens can be identified. With this information, peptides can be synthesized and used in an attempt to generate antigen-specific antisera. This approach has been successfully applied in our laboratory for generating antisera against the C-domain regions of two PSG products, i.e., PSG1d and PSG3, and development of further antisera is in progress. Similarly, Tsujisaki et al. (128) have raised antibodies against CEA peptides, some of which also recognize purified CEA.

Other investigations have been performed, or are in progress, to locate and better characterize the natural epitopes on CEA-related molecules. Although they are heavily glycosylated, most anti-CEA monoclonal antibodies have been shown to bind the polypeptide moiety (15). Mapping has been carried out for epitopes on the NCA protein by progressive deletion from the C-terminal end of an NCA cDNA clone and expression as a fusion protein with the $\beta$-galactosidase of $E$. coli (129). In this manner, two epitopes were mapped to the $\mathrm{N}$-terminal domain, one being present on NCA and not CEA, and the second is common to both. Site-directed mutagenesis was used to determine the exact location of the NCA-specific epitope. Using a similar approach, Hass et al. (130) recently determined the location of different epitopes on the CEA polypeptide chain. These authors synthesized the four principal domains (N, A1B1, A2B2, and A3B3) and expressed them in $E$. coli as fusion products with bacterial CMP-KDO synthetase. Three groups of monoclonal antibodies were identified: the first only recognized a single domain, the second showed preferential binding to one domain but some cross-reactivity with one or more additional domains, and the third bound more than one domain equally well.

An amplification of effectivity in the use of CEA as a tumor marker has been achieved by using more than one specific antibody for determining serum values as well as for immunolocalization or immunotherapy purposes (131). For this reason it is important to characterize the different epitopes, so that competition in binding does not result. In this context, many laboratories have exchanged their CEA-specific antibodies, which have been independently compared by using standard reagents (15). The authors compared the reactivity of 52 monoclonal antibodies and the results indicate the existence of five epitope groups (Gold groups), whereby two groups generally show high CEA specificity. Application of antibodies from different Gold groups should lead to multiple CEA binding. This type of multiple binding has the addi- 
tional advantage of avoiding potential problems arising through the heterogeneity of CEA from different patients, caused mainly by variability in the carbohydrate moieties, which could mask epitopes to varying degrees. Taking this into account, many of the commercially available CEA-assay kits for determining CEA serum levels include mixtures of monoclonal anti-CEA antibodies rather than use single ones.

\section{POST-TRANSLATIONAL MODIFICATIONS OF CEA- RELATED ANTIGENS}

One major difficulty regarding the assignment of antigens to their mRNAs is caused by post-translational modification of CEA-related antigens. It has been known for a long time that the CEA family members are heavily glycosylated, and the carbohydrate moiety comprises $30 \%$ of the total molecular weight in PSGs (107) and rises up to $60 \%$ in mature CEA (reviewed in 11). It may be expected that such heavy glycosylation can hinder the binding of antibodies to protein epitopes, or be antigenic in itself $(15,132)$.

The monosaccharide composition of CEA was found to contain large amounts of glucosamine, but only negligible amounts of galactosamine $(133,134)$. This indicates that the sugar chains are mostly asparagine linked. As deduced from cDNA cloning $(95,105,106,135)$, CEA contains 28 potential glycosylation sites. Assuming that all sites are glycosylated, and in order to achieve a molecular weight of 180,000 , the carbohydrate chain length must average 20 monosaccharide residues. Analysis of the CEA carbohydrate chains supports this calculation, whereby the chains have tetraantennary $(80 \%)$, triantennary $(15 \%)$, or diantennary $(5 \%)$ structures (136). Kobata et al. (137) have analysed the carbohydrate moieties of three CEA samples and an NCA-2 sample (a NCA species isolated from meconium). They found differences in the sugar chain compositions of these two antigens. Whereas the CEA carbohydrate moiety includes high-mannose-type sugar chains, this type is absent from NCA-2. Differences in the complextype, outer chain, sugar moieties were also found between the two antigens. Nagata et al. (138) recently tested the binding affinities of different lectins with CEA isolated from different tissues. Variability in the major sugar chains was determined, depending on the CEA source; i.e., CEA isolated from the seminal plasma, meconium, and colon adenocarcinomas were all different. This variability is probably due, at least in part, to the differences in the fetal and adult glycosylation systems (139).

Variability in the degree of glycosylation has also been shown for the CEA-related TEX $\left(M_{r} 75,000\right)$ and NCA $\left(M_{r}\right.$ $45,000)$ proteins $(110)$. It was found by protein sequencing and fast bombardment mass spectrometry that the two antigens have the same protein backbone, corresponding to that derived from NCA cDNA clones $(105,140,141)$. In both cases, all 12 predicted asparagine-linked glycosylation sites were found to be glycosylated. The differences in the molecular weights suggest significant variations in their oligosaccharide structures. These two molecules correspond to NCA-50/ 90 , which has independently been shown by protein sequencing to be encoded by the NCA gene (51, Table 3 ).

A second type of post-translational modification is the replacement of the hydrophobic $\mathbf{M}$ domain with a glycosyl phosphatidylinositol (GPI) moiety, which anchors some members of the human CEA-related subgroup into the plasma membrane. The relevance of GPI anchorage is unknown, but it is a widespread phenomenon for the binding of many membrane proteins in eukaryotes (142). These proteins can be released from the membrane by digestion with phosphatidylinositolspecific phospholipases C or D (PI-PLC, PI-PLD). It is possible that the release of CEA into the serum is controlled in vivo by such phospholipases, thereby regulating the amount of membrane-bound protein. Such a mechanism could explain the rapid turnover of CEA in the mucosa of the normal intestine (100). Furthermore, variability in enzyme activity could also explain why for some CEA-producing tumors high serum levels are found whereas for others low levels exist, despite high CEA concentrations in the tumors (143-145). GPIanchored proteins reveal a more rapid lateral mobility in membranes than integral membrane proteins, which could have functional consequences (reviewed in 142). In addition, GPIanchored proteins are more often found to be located toward the apical surface in polarized cells than the basal region, which indicates a selective sorting mechanism (146). A special function for the GPI anchor in CEA-related molecules remains to be determined. Some CEA-related molecules are integral membrane proteins (Fig. 1). Similar variability in the type of membrane anchorage has been described for N-CAM (147), LFA-3 (148,149), and FcyIII receptors (150).

A third type of post-translational modification which has been reported for CEA-related molecules is phosphorylation. Margolis et al. $(151,152)$ have reported that the rat ecto-ATPase is identical to $\mathrm{pp} 120 / \mathrm{HA} 4$, which was previously shown to be a substrate for the insulin-induced tyrosine kinase (153155). After hormone binding, the intrinsic tyrosine kinase of the $\beta$-subunit of the insulin receptor is activated and phosphorylates itself (156), as well as several membrane-bound and cytosolic substrates (157). Interestingly, the CEA-related antigen bearing the CD66 epitope (111) has been described as an $\mathbf{M}_{\mathbf{r}}$ of $180,000-200,000$ phosphorylated protein (112).

\section{REGULATION OF EXPRESSION OF CEA-RELATED GENES}

Despite their high sequence similarities, the various members of the CEA family reveal very different expression patterns, as already discussed. It is of interest to determine what regulates this differential expression. In general, it is known that regulation of expression can take place at various levels. At the basic level, gene amplification has been reported to increase the expression of certain genes, e.g., N-myc in neu- 
roblastomas (158), but for CEA-related genes, no evidence has so far been found to indicate that this occurs $(10,159)$. However, regulation may occur through base modification at the DNA level. The degree of DNA methylation in and around CEA-related genes has been shown to correlate with CEA expression in different cell lines (159). The same authors found that tumor cells expressing high amounts of CEA showed hypomethylation of CEA-related genes, whereas these genes are hypermethylated in normal fibroblast cell lines which do not express CEA.

The next possible level of regulation is at the transcriptional level. This does play a role for members of the CEA family, because transcripts for individual members have only been found in certain tissues, indicating either tissue-specific transcriptional regulation or differences in the mRNA stabilities. As a basis for studying regulation at this level, the transcriptional start sites of two human PSG genes $(61,107)$, the CEA and NCA genes $(71,106)$, and two rodent PSG genes, rnCGM1 and mmCGM5 $(30,32)$, have been determined. Sequence analysis of the putative promoter regions reveal that all these CEA-related genes lack the typical TATA- and CAATbox sequences found in many other gene promoters (160). A number of genes which also lack TATA boxes have been described, including genes which are regulated during differentiation of mammalian lymphocytes, e.g., 'T-cell receptor $\beta$-chain genes (161), $V_{\text {preB }}$ gene (162), and the terminal transferase gene (163), as well as some Drosophila homeotic genes (164-166). On comparing the sequences of all known CEArelated genes upstream from the translational start sites, it is obvious that despite relatively high sequence divergence, a conserved region exists which correlates with the transcriptional start sites of a number of these genes. Band-shift analyses in our laboratory (32) have revealed binding of proteins which are apparently ubiquitous to this region, i.e., similar binding patterns are found using nuclear extracts from a variety of human and rodent tissues or cell lines. This indicates that alternative sequences to the TATA box may exist which define the transcriptional start sites for CEA-related genes.

Functional assays were used to determine a cell-type-specific promoter region for the CEA gene $(71,167)$. It was found that a region located within 112 nucleotides upstream from the transcriptional start site is responsible for conveying an approximately $10 \times$ higher transcriptional activity in a human CEA-producing adenocarcinoma cell line (SW403) compared to a non-producing human cell line (HeLa). These results indicate the presence of an element within the CEA promoter which may be responsible for tissue-specific expression, although this needs closer examination.

As mentioned above, higher steady-state levels exist for NCA transcripts in colonic tumors compared to the normal colonic mucosa. This suggests either an up-regulation of the NCA transcription rate or an increased half-life of NCA transcripts in tumors. Further studies designed to compare the rates of transcription must be carried out before this can be clarified.
The expression patterns exhibited by the human and rodent PSG genes indicate coordinated transcriptional activity in the placenta $(27,61,102)$. Analyses at the genomic level show that the PSG genes are closely linked in humans $(61,69)$ and in mouse (32), which could facilitate coordinated expression through the use of common regulatory elements. Similar mechanisms may also regulate the expression of the CEA subgroup genes (Fig. 3). As discussed, CEA transcripts are often but not always coexpressed with NCA transcripts, as shown in various tumors. Their direct physical linkage indicates that common cis-acting elements may exist there too. For the $\beta$-globin gene family, it is known that the order of the genes within that gene cluster represents the order in which they are expressed during ontogenesis (168). Similarly, the positional expression pattern of homeotic genes in Drosophila and of their mouse counterparts, the Hox genes along the anterior/posterior axis of these organisms, has been shown to be colinear with the gene order within those clusters (169). It will be interesting to see whether variability in the temporal or spatial expression patterns of CEA-related molecules correlates with their genomic order. Indeed, a differential temporal expression of mouse subgroup 2 (Table 2) genes during placental development has been found in our laboratory (32). Using probes from different cDNA clones, a $3.3 \mathrm{~kb}$ mRNA species (possibly encoded by mmCGM7) was identified in mouse placental extracts from day 11 of gestation, but this transcript is drastically reduced at day 13. The situation is reversed for two $2.2 \mathrm{~kb}$ transcripts (encoded by mmCGM5 and mmCGM6), which are not present at day 11 but appear at day 13 .

Regulation of expression may also occur at the translational or post-translational levels. An example for such regulation in the CEA family has been documented. Although colonic tumors contain on average much higher CEA concentrations than the normal colonic mucosa, the steady-state levels of CEA transcripts are comparable $(10,95,100,101)$. Using organ cultures, Kuroki et al. (100) found that CEA was synthesized in equal amounts by normal colon and colonic adenocarcinomas, from which they concluded that CEA has a more rapid turnover in normal colon, where it is quickly shed and excreted via the feces. In this context, the normal fecal antigens (NFA) reported as representing CEA-related molecules (170) probably represent CEA breakdown products (Table 3), e.g., the $\mathrm{N}$-terminal nine amino acids of NFAl are identical with the start of the A2 domain in CEA (170). Thus, the steady-state CEA protein levels in colonic tumors are much higher, possibly because the CEA cannot be excreted via the intestinal lumen.

Knowledge of the regulation of expression of CEA is of both fundmental and clinical interest. Possibly, stimulating CEA expression in vivo would help in binding more CEAspecific antibodies at the tumor site for immunolocalization or immunotherapeutic purposes. A number of substances have been described which up-regulate the expression of CEA- 
related molecules in vitro, including several agents known to stimulate cellular differentiation, e.g., $\alpha-, \beta$-, and $\gamma$-interferon $(159,171-174))$, theophyllin (175), several polar organic solvents (176), cyclic AMP (177), sodium butyrate (178-180), transforming growth factor (TGF)- $\beta 1$ and $-\beta 2(181,182)$, and retinoids (183).

\section{FUNCTIONS OF CEA-RELATED MOLECULES}

One of the most intriguing aspects of the CEA family relates to its function(s). Through molecular cloning and analysis of the derived protein structures, the relationship to the immunogobulin supergene family gave first indications regarding possible functions. Sequence comparisons of members of this superfamily have helped to differentiate two sets of constantlike domains, $\mathrm{C} 1$ and $\mathrm{C} 2(39,40)$. Members of the $\mathrm{C} 1$-set are directly involved with immunorecognition, e.g., immunoglobulin heavy and light constant chains, T-cell receptor $\beta$ - and $\gamma$-chains, as well as major histocompatibility $\alpha$ - and $\beta$-chains. The $\mathrm{C} 2$-set includes a number of cell adhesion molecules, e.g., neural cell adhesion molecule $(184,185)$, myelinassociated glycoprotein $(186,187), \mathrm{CD} 2(188,189)$, ICAM-1 (190), and ICAM-2 (191) as well as some cell surface receptors, e.g., platelet-derived growth factor receptor (192) and Fc-receptor $(193,194)$. CEA-related molecules are also included in the $\mathrm{C} 2$-set and this finding led to directed experiments to test for cell adhesion functions for chosen CEA family members.

In the meantime, cell adhesion properties have been well established in vitro for CEA, NCA, BGP, and the product of the rodent gene mmCGM2 (31,90-93). Indeed, in rat, the C-CAM molecule was originally isolated because of its adhesive properties in aggregating hepatocytes $(35,195)$. It is interesting to note that BGP and mmCGM2 are reportedly temperature and calcium dependent in their binding capabilities $(31,93)$, a property characteristic of the cadherin family of adhesion molecules $(196,197)$. CEA and NCA on the other hand are neither calcium nor temperature dependent, a feature more typical of other immunoglobulin-related adhesion molecules (125). Both homophilic (e.g., CEA binding to CEA) and heterophilic (e.g., CEA binding to NCA) interactions have been reported. The adhesive strength, based on the speed of aggregation, the final percentage of single cells, and the size of the aggregates for a large number of transfectants varies for these molecules in the order CEA $>$ NCA $>$ BGP for homophilic interactions $(90,93)$.

Cell adhesion is known to be important during embryonic development, where intercellular interactions occur between migrating and fixed cells in the determination of animal form during organogenesis (198). Indeed, the expression pattern of CEA-related transcripts found in mesenchymal tissues during mouse embryonic development is reconcilable with such an in vivo adhesive function for the resulting proteins (123). However, a cell adhesion function is difficult to envisage in the normal intestine, because CEA is mainly found on the brush border toward the lumen (199). Nevertheless, Öbrink (125) speculates that mouse C-CAM, or C-CAM-related molecules (Table 2), which are also located on the microvilli of the small intestinal brush border, may be responsible for determining the proper organization of these microvilli.

A similar cell-cell adhesion function for the PSG molecules is also difficult to imagine because the majority are apparently not membrane-bound but are secreted instead. Despite this, they could mediate binding to cellular matrices. The derived amino acid sequences of most but not all PSG proteins contain the tripeptide sequence arginine-glycine-aspartic acid (RGD) in their N-terminal domains, which has been reported in a number of substrate adhesion molecules such as fibronectin (200) to be responsible for interactions with specific receptors on cell membranes. These cells then become anchored to the matrix. It remains to be determined if this sequence plays a similar role in PSG. Three PSG species (PSG1, PSG4, and PSG8) lack this tripeptide sequence, and it is noteworthy that they all belong to subclass 1 in Figure 5. These molecules may indeed have different or modified functions relative to the other PSG. The fact that PSG are produced at very high levels by the placenta (87) and that low serum levels in pregnant women correlate with threatened abortion (201) indicates an important function during pregnancy. The suggestion that PSG may protect the developing fetus from the maternal immune system is an interesting working hypothesis for designing experiments.

Apart from cellular adhesion, other potential functions have recently been proposed for CEA-related molecules. It has been reported that both CEA and NCA have a specific affinity for binding certain strains of $E$. coli bacteria, which are found in the human intestinal flora (202). This has been demonstrated in vitro and is apparently achieved via a bacterial lectin/CEA carbohydrate interaction. Such a function is possible for CEA only in the normal adult colonic mucosa, which could facilitate bacterial colonization of the intestine. In this context, the rapid shedding of CEA into the lumen may represent a mechanism for regulating the steady-state level of bacteria present. NCA on the surface of granulocytes could specifically bind invading bacteria via this lectin/carbohydrate interaction, thus facilitating phagocytosis (202).

A third possible function is one in which CEA plays an accessory role in the in vitro binding of a colonic adenocarcinoma cell line (SW1222) to collagen type I (203), which again is hard to envisage in the normal colon. However, in migrating embryonic cells as well as metastasizing tumor cells, this may be important in mediating interactions with basement membranes. Furthermore, assuming a similar function for NCA, this could have importance in interactions between granulocytes and endothelial basement membranes, which are necessary before these phagocytic cells can penetrate tissues to reach regions of inflammation.

Sequence homology to a putative rat ecto-ATPase would 
suggest a possible enzymatic function for members of the CEA family (33). Such a function could regulate the adhesive properties of CEA-related molecules, as the rat ecto-ATPase was found to be identical to C-CAM (124), which was described as responsible for the adhesion of aggregating rat hepatocytes (35). It is noteworthy that the addition of exogenous ATP has been reported to inhibit, whereas ADP stimulated aggregation of mouse liver cells (204). Furthermore, granulocytes can secrete ATP with which they could regulate their own adhesive properties (205).

Most of the above functions have been determined in vitro but remain to be confirmed in vivo. Such investigations cannot be carried out in humans, but the animal model offers possibilities, e.g., through inhibition of specific gene expression by homologous recombination with defective gene constructs in transgenic mice (206). Any ensuing phenotypic abnormalities could help in understanding the in vivo functions.

Finally, the role of CEA in directing metastases from colorectal cancers to the liver has also been discussed (reviewed in 207). Hostetter et al. (208) showed that after transplantation of human colorectal tumors in athymic nude mice, the number of liver metastases increased from $2 \%$ to $48 \%$ on preinjection of the mice with CEA. A possible explanation for this is the binding of CEA via a specific receptor known to exist on Kupffer cells $(88,89)$ and a homophilic binding of this CEA with CEA on the surface of metastatic colorectal tumor cells, which then become immobilized and develop secondary tumors (207).

\section{CLINICAL OUTLOOK}

Based on the data gained so far, a number of methods are available which should help to determine more exactly as well as increase the clinical reliability of CEA. Existing antibodies are in the process of being tested for specificity against panels of transfectants expressing individual CEA-related molecules. With the development of anti-CEA antibodies raised against synthetic peptides, this should increase the availability of defined antibodies. Furthermore, it is becoming obvious that other members of the CEA family may also be useful as tumor markers, e.g., NCA in colonic tumors. It may be that the combined expression pattern of more than one member of the CEA family could be utilized for diagnosis of tumors of unknown origin when interpretation of histological data is difficult, as well as in the determination of whether a tumor is benign or malignant providing that variability of expression exists. Before such questions can be answered, however, statistical evaluation of the expression patterns for the different family members must be carried out, e.g., by polymerase chain reaction combined with in situ hybridization data and immunohistology.

The usefulness of specific antibodies for immunolocalization or for immunotherapy is already obvious, although other problems also exist, e.g., uptake of antibodies in unwanted cells, binding of the antibody by circulating antigen, modulation, masking, or loss of the antigen from the tumor cell and immunogenicity of the heterologous antibodies used (209). In order to circumvent at least some of these problems, antibodies can be engineered with the help of molecular biological methods, without losing their specificity. Experiments along these lines have already been carried out for CEA-specific monoclonal antibodies (210-212). To avoid immunogenicity of the antibodies following repeated administration, chimaeric monoclonal antibodies have been generated. The murineconstant region segments of the $\mathrm{H}$ - and L-polypeptides, not involved in antigen recognition, were replaced by human Ig-constant regions. This type of engineering not only removes many murine antigenic determinants but also introduces effector recognition regions, e.g., for binding of human complement factors, Fc-receptor, etc. In this way, the patient's own effector functions could become activated, once antibodies are concentrated at the tumor site.

Another interesting approach which is also based on activation of the immune system against tumors involves immunizing with anti-idiotypic antibodies which mimic a tumor antigen, e.g., CEA. This type of immunization should have the advantage over immunization with the antigen itself, which would lead to the production of antisera recognizing not only CEA, but also all crossreacting antigens. For immunization, antibodies specific for CEA could be used, thus circumventing these problems. Tsujisaki et al. (213) reported the development of such anti-idiotypic antibodies, which were indeed recognized by polyclonal antisera raised against CEA. Similar results have also been reported by two other groups $(214,215)$.

The animal model system should help with preclinical trials for testing the efficacy of monoclonal antibodies in the immunotherapy of CEA-producing tumors. Once regulatory regions have been determined, which direct the expression of CEA in colonic tissues, constructs may be utilized for making transgenic mice, whereby induced colonic tumors should express human CEA. Different antibodies could be tested individually or in combination, and also together with other types of therapy, so that the optimal approach can be developed in vivo, prior to application in cancer patients. Furthermore, the expression of CEA could be up-regulated by addition of different substances known to have this effect in vivo, in an attempt to increase its concentration and thereby the concentration of labelled anti-CEA antibodies at the tumor site.

Therefore, although much work still remains to be done, the foundations have been laid for the directed use of CEArelated molecules in the fight against cancer, and further experimentation should help to optimize their applications for the future.

\section{ACKNOWLEDGMENTS}

We would like to thank Drs. Beauchemin, Hammarström, Henslee, Imai, Jessup, Matsuoka, and Öbrink for forward- 
ing their latest data on various aspects of the biology of CEArelated molecules. We also wish to acknowledge permission from Drs. Chan, Eades-Perner, Hardman, Khan, Mansfield, Matsuoka, Mohrenweiser, Nagel, Niemann, Saunders, Seldin, and Willcocks to cite unpublished data. A special thank-you to Drs. von Kleist, Eades-Perner, and Nagel for critical reading of the manuscript and to all our colleagues in Freiburg for their continual support, especially F. Jehle for computer assistance.

Our work was supported by grants from the "Deutsche Forschungsgemeinschaft" and the "Mildred Scheel Stiftung für Krebsforschung. ',

\section{REFERENCES}

1. Edwards BK: Worldwide cancer cases. JNCI 83:238, 1991.

2. Sell S: Cancer markers of the 1990s. Comparison of the new generation of markers defined by monoclonal antibodies and oncogene probes to prototypic markers. Clin Lab Med 10:1-37, 1990.

3. Gold P, Freedman SO: Demonstration of tumor-specific antigens in human colonic carcinomata by immunological tolerance and absorption techniques. $J$ Exp Med 121:439-462, 1965.

4. Gold P, Freedman SO: Specific carcinoembryonic antigens of the human digestive system. $J$ Exp Med 122:467-481, 1965.

5. Von Kleist S, Burtin P: Localisation cellulaire d'un antigèn embryonnaire de tumeurs coliques humaines. Int J Cancer 4:874-879, 1969.

6. Chu TM, Reynoso G, Hansen HJ: Demonstration of carcinoembryonic antigen in normal human plasma. Nature 238:152-153, 1972.

7. Kupchik HZ, Zamcheck N: Carcinoembryonic antigen(s) in liver disease. Isolation from human cirrhotic liver and serum and from normal liver. Gastroenterology 63:95-101, 1972.

8. Egan ML, Pritchard DG, Todd CW, Go VLW: Isolation and immunochemical and chemical characterization of carcinoembryonic antigenlike substances in colon lavages of healthy individuals. Cancer Res 37:2638-2643, 1977.

9. Fritsche R, Mach J-P: Isolation and characterization of carcinoembryonic antigen (CEA) extracted from normal human colon mucosa. Immunochemistry 14:119-127, 1977.

10. Boucher D, Cournoyer D, Stanners CP, Fuks A: Studies on the control of gene expression of the carcinoembryonic antigen family in human tissue. Cancer Res 49:847-852, 1989.

11. Thompson J, Zimmermann W: The carcinoembryonic antigen gene family: Structure, expression and evolution. Tumor Biol 9:63-83, 1988.

12. Shively JE, Beatty JD: CEA-related antigens: Molecular biology and clinical significance. CRC Crit Rev Oncol Hematol 2:355-399, 1985.

13. Fantini GA, DeCosse JJ: Surveillance strategies after resection of carcinoma of the colon and rectum. Surg Gynecol Obstet 171:267-273, 1990.

14. Von Kleist S: Das karzinoembryonale Antigen (CEA). Biologische Grundlagen und klinische Anwendung. Schattauer-Verlag, Stuttgart/New York, 1983.

15. Hammarström S, Shively IE, Paxton RJ, Beatty BG, Larsson Å, Ghosh R, Börmer $O$, Buchegger F, Mach J-P, Burtin P, Seguin P, Darbouret B, Degorce F, Sertour J, Jolu JP, Fuks A, Kalthoff H, Schmiegel W, Amdt R, Klöppel G, von Kleist S, Grunert F, Schwarz K, Matsuoka Y, Kuroki M, Wagener C, Weber T, Yachi A, Imai K, Hishikawa N, Tsujisaki M: Antigenic sites in carcinoembryonic antigen. Cancer Res 49:4852-4858, 1989.

16. Goldenberg DM: Current status of cancer imaging with radiolabeled antibodies. J Cancer Res Clin Oncol 113:203-208, 1987.

17. Beatty JD, Duda RB, Williams LE, Sheibani K, Paxton RJ, Beatty BG, Philben VJ, Werner JL, Shively JE, Vlahos WG, Kokal WA,
Riihimaki DU, Terz JJ, Wagman LD: Preoperative imaging of colorectal carcinoma with $111 \mathrm{In}$-labeled anticarcinoembryonic antigen monoclonal antibody. Cancer Res 46:6494-6502, 1986.

18. Bischoff-Delaloye A, Delaloye B, Buchegger F, Gilgien W, Studer A, Curchod S, Givel J-C, Mosimann F, Pettavel J, Mach J-P: Clinical value of immunoscintigraphy in colorectal carcinoma patients: a prospective study. J Nucl Med 30:1646-1656, 1989.

19. Sharkey RM, Weadock KS, Natale A, Haywood L, Aninipot R, Blumenthal RD, Goldenberg DM: Successful radioimmunotherapy for lung metastasis of human colonic cancer in nude mice. JNCI 83:627-632, 1991.

20. Buchegger F, Vacca A, Carrel S, Schreyer M, Mach J-P: Radioimmunotherapy of human colon carcinoma by $\left[{ }^{131} \mathrm{I}\right]$-labelled monoclonal anti-CEA antibodies in a nude mouse model. Int J Cancer 41:127-134, 1988.

21. Von Kleist S, Chavanel G, Burtin P: Identification of an antigen from normal human tissue that crossreacts with the carcinoembryonic antigen. Proc Natl Acad Sci USA 69:2492-2494, 1972.

22. Mach J-P, Pusztaszeri G: Carcinoembryonic antigen (CEA): demonstration of a partial identity between CEA and a normal glycoprotein. Immunochemistry 9:1031-1034, 1972.

23. Svenberg T: Carcinoembryonic antigen-like substances of human bile: Isolation and partial characterization. Int J Cancer 17:588-596, 1976.

24. Tatarinov YS, Masyukevich VN: Immunological identification of a new $\beta 1$-globulin in the blood serum of pregnant women. Byull Eksp Biol Med 69:66-68, 1970.

25. Bohn H: Nachweis und Charakterisierung von Schwangerschaftsproteinen in der menschlichen Placenta, sowie ihre quantitative immunologische Bestimmung im Serum schwangerer Frauen. Arch Gynäkol 210:440-457, 1971.

26. Barnett T, Zimmermann W: Proposed nomenclature for the carcinoembryonic antigen (CEA) gene family. Tumor Biol 11:59-63, 1990.

27. Kodelja V, Lucas K, Barnert S, von Kleist S, Thompson JA, Zimmermann $W$ : Identification of a carcinoembryonic antigen gene family in the rat: Analysis of the $\mathrm{N}$-terminal domains reveals immunoglobulinlike, hypervariable regions. J Biol Chem 264:6906-6912, 1989.

28. Beauchemin N, Turbide C, Afar D, Bell J, Raymond M, Stanners CP, Fuks A: A mouse analogue of the human carcinoembryonic antigen. Cancer Res 49:2017-2021, 1989.

29. Beauchemin N, Turbide C, Huang JQ, Benchimol S, Jothy S, Shirota K, Fuks A, Stanners CP: Studies on the function of carcinoembryonic antigen. In The Carcinoembryonic Antigen Gene Family. A Yachi, J Shively, eds. Elsevier Science Publishers, BV, Amsterdam, 1989, p 49-64.

30. Rebstock S, Lucas K, Thompson JA, Zimmermann W: cDNA and gene analyses imply a novel structure for a rat carcinoembryonic antigenrelated protein. J Biol Chem 265:7872-7879, 1990.

31. Turbide C, Rojas M, Stanners CP, Beauchemin N: A mouse carcinoembryonic antigen gene family member is a calcium-dependent cell adhesion molecule. J Biol Chem 266:309-315, 1991.

32. Rudert F: Isolierung von Mitgliedern der karzinoembryonalen Antigen (CEA)-Genfamilie der Maus und Analyse potentieller Promotor/ Enhancer-Bereiche. Doctoral thesis, University of Freiburg, 1991.

33. Lin S-H, Guidotti G: Cloning and expression of a cDNA coding for a rat liver plasma membrane ecto-ATPase. J Biol Chem 264:14408-14414, 1989.

34. Lin S-H: Localization of the ecto-ATPase (ecto-nucleotidase) in the rat hepatocyte plasma membrane. J Biol Chem 264:14403-14407, 1989.

35. Ocklind C, Öbrink B: Intercellular adhesion of rat hepatocytes. Identification of a cell surface glycoprotein involved in the initial adhesion process. J Biol Chem 257:6788-6795, 1982

36. Rudert F, Zimmermann W, Thompson JA: Intra- and interspecies analyses of the carcinoembryonic antigen (CEA) gene family reveal independent evolution in primates and rodents. J Mol Evol 29:126-134, 1989. 
37. Streydio C, Swillens S, Georges M, Szpirer C, Vassart G: Structure, evolution and chromosomal localization of the human pregnancy-specific $\beta 1$ glycoprotein gene family. Genomics 6:579-592, 1990.

38. Paxton R, Mooser G, Pande H, Lee TD, Shively JE: Sequence analysis of carcinoembryonic antigen: Identification of glycosylation sites and homology with the immunoglobulin supergene family. Proc Natl Acad Sci USA 84:920-924, 1987.

39. Williams AF: A year in the life of the immunoglobulin superfamily. Immunol Todary 8:298-303, 1987.

40. Williams AF, Barclay AN: The immunoglobulin superfamily-domains for cell surface recognition. Annu Rev Immunol 6:381-405, 1988

41. Thompson J, Barnert S, Berling B, von Kleist S, Kodelja V, Lucas K, Mauch E-M, Rudert F, Schrewe H, Weiss M, Zimmermann W: Structure, expression and evolution of the human and rat carcinoembryonic antigen (CEA) gene families. In The Carcinoembryonic Antigen Gene Family. A Yachi, JE Shively, eds. Elsevier Science Publishers, BV, Amsterdam, 1989, p 65-74.

42. Thompson JA, Mauch E-M, Chen F-S, Hinoda Y, Schrewe H, Berling B, Barnert S, von Kleist S, Shively JE, Zimmermann W: Analysis of the size of the carcinoembryonic antigen (CEA) gene family: Isolation and sequencing of $\mathrm{N}$-terminal domain exons. Biochem Biophys Res Commun 158:996-1004, 1989

43. Hinoda Y, Neumaier M, Hefta SA, Drzeniek Z, Wagener C, Shively L, Hefta LJF, Shively JE, Paxton RJ: Molecular cloning of a cDNA coding biliary glycoprotein I: Primary structure of a glycoprotein immunologically crossreactive with carcinoembryonic antigen. Proc Natl Acad Sci USA 85:6959-6963, 1988.

44. Barnett TR, Kretschmer A, Austen DA, Goebel SJ, Hart JT, Elting JJ, Kamarck ME: Carcinoembryonic antigens: Alternative splicing accounts for the multiple mRNAs that code for novel members of the carcinoembryonic antigen family. J Cell Biol 108:267-276, 1989.

45. Kurroki M, Arakawa F, Matsuo Y, Oikawa S, Misumi Y, Nakazato H, Matsuoka Y: Molecular cloning of nonspecific cross-reacting antigens in human granulocytes. $J$ Biol Chem (in press).

46. Hefta SA, Hefta LJF, Lee TD, Paxton RJ, Shively JE: Carcinoembryonic antigen is anchored to membranes by covalent attachment to a glycosylphosphatidylinositol moiety: Identification of the ethanolamine linkage site. Proc Natl Acad Sci USA 85:4648-4652, 1988.

47. Takami N, Misumi Y, Kuroki M, Matsuoka Y, Ikehara Y: Evidence for carboxyl-terminal processing and glycolipid-anchoring of human carcinoembryonic antigen. J Biol Chem 263:12716-12720, 1988.

48. Jean F, Malapert P, Rougon G, Barbet J: Cell membrane, but not circulating, carcinoembryonic antigen is linked to a phosphatidylinositolcontaining hydrophobic domain. Biochem Biophys Res Commun 155:794-800, 1988.

49. Sack TL, Gum JR, Low MG, Kim YS: Release of carcinoembryonic antigen from human colon cancer cells by phosphatidylinositol-specific phospholipase C. J Clin Invest 82:586-593, 1988.

50. Grunert F, Kolbinger F, Schwarz K, Schwaibold H, von Kleist S: Protein analysis of NCA-50 shows identity to NCA cDNA deduced sequences and indicates posttranslational modifications. Biochem Biophys Res Commun 153:1105-1115, 1988.

51. Kolbinger F, Schwarz K, Brombacher F, von Kleist S, Grunert F: Expression of an NCA cDNA in NIH/3T3 cells yields a $110 \mathrm{~K}$ glycoprotein, which is anchored into the membrane via glycosyl-phosphatidylinositol. Biochem Biophys Res Commun 161:1126-1134, 1989.

52. Hefta LJF, Schrewe H, Thompson JA, Oikawa S, Nakazato H, Shively JE: Expression of complementary DNA and genomic clones for carcinoembryonic antigen and nonspecific cross-reacting antigen in Chinese hamster ovary and mouse fibroblast cells and characterization of the membrane-expressed products. Cancer Res 50:2397-2403, 1990.

53. Arakawa F, Kuroki M, Misumi Y, Oikawa S, Nakazato H, Matzuoka $Y$ : Characterization of a cDNA clone encoding a new species of the nonspecific cross-reacting antigen (NCA), a member of the CEA gene family. Biochem Biophys Res Commun 166:1063-1071, 1990.
54. Berling B, Kolbinger F, Grunert F, Thompson JA, Brombacher F, Buchegger F, von Kleist S, Zimmermann W: Cloning of a carcinoembryonic antigen family member expressed in leukocytes of chronic myeloid leukaemia patients and bone marrow. Cancer Res 50:6534$6539,1990$.

55. Khan $W N$, Hammerström $S$ : Carcinoembryonic antigen gene family: Molecular cloning of cDNA for a PS $\beta$ G/FL-NCA glycoprotein with a novel domain arrangement. Biochem Biophys Res Commun 161:525$535,1989$.

56. Khan WN, Osterman A, Hammarström S: Molecular cloning and expression of cDNA for a carcinoembryonic antigen-related fetal liver glycoprotein. Proc Natl Acad Sci USA 86:3332-3336, 1989.

57. Zimmermann $W$, Weiss $M$, Thompson JA: cDNA cloning demonstrates the expression of pregnancy-specific glycoprotein genes, a subgroup of the carcinoembryonic antigen gene family, in fetal liver. Biochem Biophys Res Commun 163:1197-1209, 1989.

58. Zheng Q-X, Tease LA, Shupert WL, Chan W-Y: Characterization of cDNAs of the human pregnancy-specific $\beta$ I-glycoprotein family, a new subfamily of the immunoglobulin gene superfamily. Biochemistry 29:2845-2852, 1990

59. Oikawa S, Inuzuka C, Kosaki G, Nakazato H: Exon-intron organization of a gene for pregnancy-specific $\beta 1$-glycoprotein, a subfamily member of CEA-family: Implications for its characteristic repetitive domains and C-terminal sequences. Biochem Biophys Res Commun 156:68-77, 1988.

60. Oikawa S, Inuzuka C, Kuroki M, Matsuoka Y, Kosaki G, Nakazato H: A pregnancy-specific $\beta 1$-glycoprotein, a CEA family member, expressed in a human promyelocytic leukemia cell line, HL-60: structures of protein, mRNA and gene. Biochem Biophys Res Commun 163:1021-1031, 1989.

61. Thompson J, Koumari R, Wagner K, Barnert S, Schleussner C, Schrewe H, Zimmermann W, Müller G, Schempp W, Zaninetta D, Ammaturo $D$, Hardman N: The human pregnancy-specific glycoprotein genes are tightly linked on the long arm of chromosome 19 and are coordinately expressed. Biochem Biophys Res Commun 167:848-859, 1990.

62. Kamarck ME, Elting JJ, Hart JT, Goebel SJ, Rae PMM, Nothdurft MA, Nedwin JJ, Barnett TR: Carcinoembryonic antigen family: Expression in a mouse L-cell transfectant and characterization of a partial cDNA in bacteriophage $\lambda$ gt 11. Proc Natl Acad Sci USA 84:5350-5354, 1987.

63. Barnett TR, Pickle W II, Rae PMM, Hart J, Kamarck M, Elting J: Human pregnancy-specific $\beta 1$-glycoproteins are coded within chromosome 19. Am J Hum Genet 44:890-893, 1989.

64. Schonk D, van Dijk P, Riegmann P, Trapman J, Holm C, Willcocks TC, Sillekens $P$, van Venrooij W, Wimmer E, Geurts van Kessel A, Ropers $\mathrm{H}-\mathrm{H}$, Wieringa B: Assignment of seven genes to distinct intervals on the midportion of human chromosome $19 \mathrm{q}$ surrounding the myotonic dystrophy gene region. Cytogenet Cell Genet 54:15-19, 1990.

65. Zimmermann W, Weber B, Ortlieb B, Rudert F, Schempp W, Fiebig $\mathrm{H}-\mathrm{H}$, Shively JE, von Kleist S, Thompson JA: Chromosomal localization of the carcinoembryonic antigen gene family and differential expression in various tumors. Cancer Res 48:2550-2554, 1988.

66. Willcocks TC, Craig SP, Craig IW: Assignment of the coding sequence for carcinoembryonic antigen (CEA) and normal cross-reacting antigen (NCA) to human chromosome 19q13. Ann Hum Genet 53:141-148, 1989.

67. Niemann SC, Schonk D, van Dijk P, Wieringa B, Grzeschik K-H, Bartels I: Regional localization of the gene encoding pregnancy specific beta-1-glycoprotein 1 (PSBG1) to human chromosome 19q13.1. Cytogenet Cell Genet 52:95-97, 1989.

68. Inazawa J, Abe $\mathrm{T}$, Inoue $\mathrm{K}$, Misawa $\mathrm{S}$, Oikawa $\mathrm{S}$, Nakazato $\mathrm{H}$, Yoshida MC: Regional assignment of nonspecific cross-reacting antigen (NCA) of the CEA gene family to chromosome 19 at band q13.2. Cytogenet Cell Genet 52:28-31, 1989.

69. Leslie KK, Watanabe S, Lei K-J, Chou DY, Plouzek CA, Deng H-C, 
Torres J, Chou JY: Linkage of two human pregnancy-specific $\beta 1$ glycoprotein genes: One is associated with hydatidiform mole. Proc Natl Acad Sci USA 87:5822-5826, 1990.

70. Saunders AM, Seldin MF: A molecular genetic linkage map of mouse chromosome 7. Genomics 8:525-535, 1990

71. Schrewe H, Thompson J, Bona M, Hefta LJF, Maruya A, Hassauer M, Shively JE, von Kleist S, Zimmermann W: Cloning of the complete gene for the carcinoembryonic antigen: Analysis of its promotor indicates a region conveying cell type-specific expression. Mol Cell Biol 10:2738-2748, 1990.

72. Willcocks TC, Craig IW: Characterization of the genomic organization of human carcinoembryonic antigen (CEA): Comparison with other family members and sequence analysis of the $5^{\prime}$ controlling region. Genomics 8:492-500, 1990.

73. Thompson JA, Pande H, Paxton RJ, Shively L, Padma A, Simmer RL, Todd CW, Riggs AD, Shively JE: Molecular cloning of a gene belonging to the carcinoembryonic antigen gene family and discussion of a domain model. Proc Natl Acad Sci USA 84:2965-2969, 1987.

74. Oikawa S, Kosaki G, Nakazato H: Molecular cloning of a gene for a member of carcinoembryonic antigen (CEA) gene family; signal peptide and $\mathrm{N}$-terminal domain sequences of nonspecific crossreacting antigen (NCA). Biochem Biophys Res Commun 146:464-469, 1987.

75. Chan W-Y, Borjigin J, Zheng Q-X, Shupert WL: Characterization of cDNA encoding human pregnancy-specific $\beta 1$-glycoprotein from placenta and extraplacental tissues and their comparison with carcinoembryonic antigen. DNA 7:545-555, 1988.

76. Mount SM: A catalogue of splice junction sequences. Nucleic Acids Res 10:459-472, 1982.

77. Schmid CW, Jelinek WR: The Alu family of dispersed repetitive sequences. Science 216:1065-1070, 1982.

78. Vorličková M, Kypr J, Štokrová Š, Sponar J: A Z-like form of poly(dA$\mathrm{dC}) \cdot$ poly(dG-dT) in solution? Nucleic Acids Res 10:1071-1080, 1982.

79. Tuan D, Solomon W, Li Q, London IM: The " $\beta$-like-globin" gene domain in human erythroid cells. Proc Natl Acad Sci USA 82:6384$6388,1985$.

80. Grosveld F, Blom van Assendelft G, Greaves DR, Kollias G: Positionindependent, high-level expression of the human $\beta$-globin gene in transgenic mice. Cell 51:975-985, 1987.

81. Thomas MJ, Freeland TM, Strobl JS: Z-DNA formation in the rat growth hormone gene promoter region. Mol Cell Biol 10:5378-5387, 1990.

82. Proudfoot NJ, Maniatis T: The structure of a human $\alpha$-globin pseudogene and its relationship to $\alpha$-globin gene duplication. Cell $21: 537-544,1980$.

83. Slightom JL, Blechl AE, Smithies O: Human fetal ${ }^{\mathrm{A}} \boldsymbol{\gamma}$ - and ${ }^{\mathrm{G}} \boldsymbol{\gamma}$-globin genes: complete nucleotide sequences suggest that DNA can be exchanged between these duplicated genes. Cell 21:627-638, 1980.

84. Haniford DB, Pulleyblank DE: The in vivo occurrence of Z-DNA. $J$ Biomol Struct Dyn 1:593-609, 1983.

85. Huitric E, Laumonier R, Burtin P, von Kleist $S$, Chavanel G: An optical and ultrastructural study of the localization of carcinoembryonic antigen (CEA) in normal and cancerous rectocolonic mucosa. Lab Invest 34:97-107, 1976.

86. Bordes M, Knobel S, Martin F: Carcinoembryonic antigen (CEA) and related antigens in blood cells and haematopoietic tissues. Eur J Cancer 11:783-786, 1975.

87. Lin T-M, Halbert SP, Spellacy WN: Measurement of pregnancyassociated plasma proteins during human gestation. J Clin Invest 54:576-582, 1974.

88. Toth CA, Thomas P, Broitman SA, Zamcheck N: A new Kupffer cell receptor mediating plasma clearance of carcinoembryonic antigen by the rat. Biochem J 204:377-381, 1982.

89. Toth CA, Thomas P, Broitman SA, Zamcheck N: Receptor-mediated endocytosis of carcinoembryonic antigen by rat liver Kupffer cells. Cancer Res 45:392-397, 1985.

90. Oikawa S, Inuzuka C, Kuroki M, Matsuoka Y, Kosaki G, Nakazato $\mathrm{H}$ : Cell adhesion activity of non-specific cross-reacting antigen (NCA) and carcinoembryonic antigen (CEA) expressed on CHO cell surface: Homophilic and heterophilic adhesion. Biochem Biophys Res Commun 164:39-45, 1989.

91. Benchimol S, Fuks A, Jothy S, Beauchemin N, Shirota K, Stanners $\mathrm{CP}$ : Carcinoembryonic antigen, a human tumor marker, functions as an intercellular adhesion molecule. Cell 57:327-334, 1989.

92. Zhou H, Fuks A, Stanners CP: Specificity of intercellular adhesion mediated by various members of the immunoglobulin supergene family. Cell Growth Differ 1:209-215, 1990.

93. Rojas M, Fuks A, Stanners CP: Biliary glycoprotein (BGP), a member of the immunoglobulin supergene family, functions in vitro as a $\mathrm{Ca}^{2+}$-dependent intercellular adhesion molecule. Cell Growth Differ I:527-533, 1990.

94. Kuroki M, Arakawa F, Matsuo Y, Oikawa S, Nakazato H, Matsuoka $\mathrm{Y}$ : Three novel molecular forms of biliary glycoprotein (BGP) deduced from cDNA from a human leukocyte library. Biochem Biophys Res Commun (in press).

95. Zimmermann W, Ortlieb B, Friedrich R, von Kleist S: Isolation and characterization of cDNA clones encoding the human carcinoembryonic antigen reveal a highly conserved repeating structure. Proc Natl Acad Sci USA 84:2960-2964, 1987.

96. Toribara NW, Sack TL, Gum JR, Ho SB, Shively JE, Willson JKV, Kim YS: Heterogeneity in the induction and expression of carcinoembryonic antigen-related antigens in human colon cancer cell lines. Cancer Res 49:3321-3327, 1989.

97. Sato C, Miyaki M, Oikawa S, Nakazato H, Kosaki G: Differential expression of carcinoembryonic antigen and nonspecific crossreacting antigen genes in human colon adenocarcinomas and normal colon mucosa. Jpn J Cancer Res 79:433-437, 1988.

98. Higashide T, Hinoda Y, Itoh J, Takahashi H, Satoh Y, Ibayashi Y, Imai $\mathrm{K}$, Yachi A: Detection of mRNAs of carcinoembryonic antigen and nonspecific cross-reacting antigen genes in colorectal adenomas and carcinomas by in situ hybridization. Jpn J Cancer Res 81:1149-1154, 1990.

99. Niemann SC, Flake A, Bohn H, Bartels I: Pregnancy-specific $\beta 1$-glycoprotein: cDNA cloning, tissue expression, and species specificity of one member of the PS $\beta$ G family. Hum Genet 82:239-243, 1989.

100. Kuroki M, Arakawa F, Yamamoto H, Shimura H, Ikehara Y, Matsuoka Y: Active production and membrane anchoring of carcinoembryonic antigen observed in normal colon mucosa. Cancer Lett 43:151-157, 1988.

101. Cournoyer D, Beauchemin N, Boucher D, Benchimol S, Fuks A, Stanners CP: Transcription of genes of the carcinoembryonic antigen family in malignant and nonmalignant human tissues. Cancer Res 48:3153-3157, 1988.

102. Streydio $C$, Vassart G: Expression of human pregnancy specific $\beta 1$ glycoprotein (PSG) genes during placental development. Biochem Biophys Res Commun 166:1265-1273, 1990.

103. Barnett TR, Pickle W II, Elting JJ: Characterization of two new members of the pregnancy - specific $\beta 1$-glycoprotein family from the myeloid cell line KG-1 and suggestion of two distinct classes of transcription unit. Biochemistry 29:10213-10218, 1990.

104. Hinoda Y, Imai K, Nakagawa N, Ibayashi Y, Nakano T, Paxton RJ, Shively JE, Yachi A: Transcription of biliary glycoprotein I in malignant and non-malignant human liver tissues. Int J Cancer 45:875-878, 1990.

105. Barnett T, Goebel SJ, Nothdurft MA, Elting JJ: Carcinoembryonic antigen family: Characterization of cDNAs coding for NCA and CEA and suggestion of nonrandom sequence variation in their conserved loop-domains. Genomics 3:59-66, 1988.

106. Beauchemin N, Benchimol S, Cournoyer D, Fuks A, Stanners CP: Isolation and characterization of full-length functional cDNA clones for human carcinoembryonic antigen. Mol Cell Biol 7:3221-3230, 1987.

107. Watanabe S, Chou JY: Isolation and characterization of complemen- 
tary DNAs encoding human pregnancy-specific $\beta 1$-glycoprotein. J Biol Chem 263:2049-2054, 1988.

108. Monden T, Murotani M, Higashiyama M, Kawasaki Y, Shimano T, Mori T: In situ localization of CEA gene transcripts and products. In The Carcinoembryonic Antigen Gene Family. A Yachi, JE Shively, eds. Elsevier Science Publishers, BV, Amsterdam, 1989, p 111-118.

109. Hinoda Y, Takahashi H, Higashide T, Nakano T, Arimura Y, Yoshimoto $M$, Imai $K$, Yachi A: Correlated expression of mRNAs of carcinoembryonic antigen and nonspecific cross-reacting antigen genes in malignant and nonmalignant tissues of the colon. Jpn J Clin Oncol (in press).

110. Hefta SA, Paxton RJ, Shively JE: Sequence and glycosylation site identity of two distinct glycoforms of nonspecific cross-reacting antigen as demonstrated by sequence analysis and fast atom bombardment mass spectrometry. J Biol Chem 265:8618-8626, 1990.

111. Watt SM, Sala-Newby G, Hoang T, Gilmore DJ, Grunert F, Nagel G, Murdoch SJ, Tchilian E, Lennox ES, Waldmann H: Within the haemopoietic system, CD 66 identifies a neutrophil specific epitope that is expressed by members of the CEA family of adhesion molecules. Blood (in press).

112. Knapp W, Dörken B, Rieber P, Schmidt RE, Stein H, von dem Bome AEGKr: CD antigens 1989. Int J Cancer 44:190-191, 1989.

113. Van der Schoot CE, Daams M, von dern Borne AEGKr, Skubitz KM, Skubitz APN, van Agthoven A, Brailly H, Romagné F, Lanini S, Knjep B, Civin Cl, Fackler MJ, Chorvath B, Duraj J, Bazil V, Hořejšr V, Hildreth J, Hyman J, Tetteroo PAT: Biochemical analysis of the myeloid panel. In White Cell Differentiation Antigens-Leucocyte Typing IV. W Knapp, B Dorken, WR Gilks, EP Rieber, RE Schmidt, H Stein, AEGKr von dem Borne, eds. Oxford University Press, Oxford, 1989, p 868.

114. Van der Schoot CE, Kuijpers TW, Daams M, von dem Borne AEGKr: The granulocytic CD66 and CD67 antigens belong to the CEA gene family and therefore to the Ig-Supergene family. Blood 76:196A (774), 1990.

115. Buchegger F, Schreyer M, Carrel S, Mach J-P: Monoclonal antibodies identify a CEA crossreacting antigen of $95 \mathrm{kD}$ (NCA-95) distinct in antigenicity and tissue distribution from the previously described NCA of $55 \mathrm{kD}$. Int J Cancer 33:643-646, 1984.

116. Berling B: Identfizierung, Charakterisierung und Expressionsanalyse von Mitgliedern der Karzinoembryonalen Antigen (CEA)-Genfamilie. Doctoral thesis, University of Freiburg, 1991.

117. Novak-Hofer I, Bläuenstein P, Schubiger PA: Regulation of the cell surface expression of a nonspecific cross-reacting antigen variant during differentiation of HL-60 cells. Cancer Res 50:7437-7443, 1990.

118. Borjigin J, Tease LA, Barnes W, Chan W-Y: Expression of the pregnancy-specific beta l-glycoprotein genes in human testis. Biochem Biophys Res Commun 166:622-629, 1990

119. Zoubir F, Khan WN, Hammarström S: Carcinoembryonic antigen gene family members in submandibular salivary gland: Demonstration of pregnancy-specific glycoproteins by cDNA cloning. Biochem Biophys Res Commun 169:203-216, 1990.

120. Rosen SW, Kaminska J, Calvert IS, Aaronson SA: Human fibroblasts produce "pregnancy-specific" beta-1 glycoprotein in vitro. Am J Obstet Gynecol 134:734-738, 1979.

121. Chou JY: Production of pregnancy-specific $\beta 1$-glycoprotein by human placental cells and human fibroblasts. Oncodev Biol Med 4:319-326, 1983.

122. Ogilvie S, Kvello-Stenstrom AG, Hammond G, Buhi WC, Larkin LH, Shiverick KT: Identification of proteins immunochernically related to human pregnancy-specific $\beta 1$-glycoprotein in the rat placenta. Endocrinology 125:287-294, 1989

123. Huang JQ, Turbide C, Daniels E, Jothy S, Beauchemin N: Spatiotemporal expression of murine carcinoembryonic antigen (CEA) gene farmily members during mouse embryogenesis. Development 110:573-588, 1990.

124. Aurivillius M, Hansen OC, Lazrek MBS, Bock E, Öbrink B: The cell adhesion molecule Cell-CAM 105 is an ecto-ATPase and a member of the immunoglobulin superfamily. FEBS Lett 264:267-269, 1990.

125. Öbrink B: C-CAM (Cell-CAM 105)-a member of the growing immunoglobulin superfamily of cell adhesion proteins. Bioessays (in press).

126. Odin P, Asplund M, Busch C, Öbrink B: Immunohistochemical localization of cell CAM 105 in rat tissues: Appearance in epithelia, platelets and granulocytes. J Histochem Cytochem 36:729-739, 1988.

127. Hansson M, Odin P, Johansson S, Öbrink B: Comparison and functional characterization of C-CAM, glycoprotein IIb/IIIa and integrin beta 1 in rat platelets. Thromb Res 58:61-73, 1990.

128. Tsujisaki M, Imai K, Hishikawa N, Tokuchi S, Hinoda Y, Matsukawa H, Oikawa S, Nakazato H, Yachi A: Preparation and characterization of monoclonal antibodies specific to synthetic peptide of carcinoembryonic antigen. Int $J$ Cancer (in press).

129. Schwarz K, Brückel N, Schwaibold H, von Kleist S, Grunert F: Nonspecific cross-reacting antigen: Characterization of specific and crossreacting epitopes. Mol Immunol 26:467-475, 1989.

130. Hass GM, Bolling TJ, Kinders RJ, Henslee JG, Mandecki W, Dorwin SA, Shively JE: Preparation of synthetic polypeptide domains of carcinoembryonic antigen and their use in epitope mapping. Cancer Res (in press).

131. Börmer OP, Thrane-Steen K: Epitope group specificity of six immunoassays for carcinoembryonic antigen. Tumor Biol 12:9-15, 1991.

132. Nichols EJ, Kannagi R, Hakomori S-I, Krantz MJ, Fuks A: Carbohydrate determinants associated with carcinoembryonic antigen (CEA). J Immunol 135:1911-1913, 1985.

133. Terry WD, Henkart PA, Coligan JE, Todd CW: Structural studies of the major glycoprotein in preparations with carcinoembryonic antigen activity. J Exp Med 136:200-204, 1972.

134. Matsuoka Y, Kuroki M, Koga Y, Kuriyama H, Mori T, Kosaki G: Immunochemical differences among carcinoembryonic antigen in tumor tissues and related antigens in meconium and adult feces. Cancer Res 42:2012-2018, 1982.

135. Oikawa S, Nakazato H, Kosaki G: Primary structure of human carcinoembryonic antigen (CEA) deduced from cDNA sequence. Biochem Biophys Res Commun 142:511-518, 1987.

136. Chandrasekaran EV, Davila M, Nixon DW, Goldfarb M, Mendicino $\mathrm{J}$ : Isolation and structures of the oligosaccharide units of carcinoembryonic antigen. J Biol Chem 258:7213-7222, 1983.

137. Kobata A, Totani K, Endo T, Kuroki M, Matsuoka Y, Yamashita K: Comparative study of the sugar chains of carcinoembryonic antigen and its crossreacting antigen purified from meconium. In The Carcinoembryonic Antigen Gene Family. A Yachi, JE Shively, eds. Elsevier Science Publishers, BV, Amsterdam, 1989, p 12-22.

138. Nagata A, Miura M, Komoda T: Sandwich assay for carcinoembryonic antigen with immobilized lectins and a monoclonal antibody. Tumor Biol 12:35-44, 1991 .

139. Feizi T, Childs RA: Carbohydrates as antigenic determinants of glycoproteins. Biochem J 245:1-1 1, 1987

140. Neumaier M, Zimmermann W, Shively L, Hinoda Y, Riggs AD, Shively JE: Characterization of a cDNA clone for the nonspecific cross-reacting antigen (NCA) and a comparison of NCA and carcinoembryonic antigen (CEA). J Biol Chem 263:3202-3207, 1988.

141. Tawaragi Y, Oikawa S, Matsuoka Y, Kosaki G, Nakazato H: Primary structure of nonspecific crossreacting antigen (NCA), a member of carcinoembryonic antigen (CEA) gene family, deduced from cDNA sequence. Biochem Biophys Res Commun 150:89-96, 1988.

142. Cross GAM: Glycolipid anchoring of plasma membrane proteins. Annu Rev Cell Biol 6:1-39, 1990.

143. Fiebig $\mathrm{HH}$, von Kleist $\mathrm{S}$ : Carcinoembryonic antigen (CEA) in human colorectal cancers growing subcutaneously in nude mice. $J$ Cancer Res Clin Oncol 105:238-242, 1983.

144. Martin KW, Halpern SE: Carcinoembryonic antigen production, secretion, and kinetics in BALB/c mice and nude mouse-human tumor model. Cancer Res 44:5475-5481, 1984. 
145. Von Kleist S, Wittekind C, Sandritter W, Gropp H: CEA positivity in sera and breast tumor tissues obtained from the same patients. Pathol Res Pract 173:390-401, 1982.

146. Lisanti MP, Rodriguez-Boulan E: Glycophospholipid membrane anchoring provides clues to the mechanism of protein sorting in polarized epithelial cells. TIBS 15:113-118, 1990

147. Hemperly JJ, Edelman GM, Cunningham BA: cDNA clones of the neural cell adhesion molecule (N-CAM) lacking a membrane-spanning region consistent with evidence for membrane attachment via a phosphatidylinositol intermediate. Proc Natl Acad Sci USA 83:98229826, 1986

148. Wallner BP, Frey AZ, Tizard R, Mattaliano RJ, Hession C, Sanders ME, Dustin ML, Springer TA: Primary structure of lymphocyte function-associated antigen 3 (LFA 3). JExpMed 166:923-932, 1987.

149. Dustin ML, Selvaraj P, Mattaliano RJ, Springer TA: Anchoring mechanisms for LFA-3 cell adhesion glycoprotein at membrane surface. Nature 329:846-848, 1987.

150. Ravetch JV, Perussia B: Alternative membrane forms of Fc $\gamma$ RIII (CD16) on human natural killer cells and neutrophils. J Exp Med 170:481-497, 1989.

151. Margolis RN, Taylor SI, Seminara D, Hubbard AL: Identification of $\mathrm{pp} 120$, an endogenous substrate for the hepatocyte insulin receptor tyrosine kinase, as an integral membrane glycoprotein of the bile canalicular domain. Proc Natl Acad Sci USA 85:7256-7259, 1988.

152. Margolis RN, Schell MJ, Taylor SI, Hubbard AL: Hepatocyte plasma membrane ecto-ATPase (pp120/HA4) is a substrate for tyrosine kinase activity of the insulin receptor. Biochem Biophys Res Commun 166:562-566, 1990.

153. Rees-Jones RW, Taylor SI: An endogenous substrate for the insulin receptor-associated tyrosine kinase. J Biol Chem 260:4461-4467, 1985.

154. Accili D, Perrotti N, Rees-Jones R, Taylor SI: Tissue distribution and subcellular localization of an endogenous substrate ( $\mathrm{pp} 120)$ for the insulin receptor-associated tyrosine kinase. Endocrinology 119:1274-1280, 1986.

155. Perrotti N, Accili D, Marcus-Samuels B, Rees-Jones RW, Taylor SI: Insulin stimulates phosphorylation of a $120-\mathrm{kDa}$ glycoprotein substrate (pp120) for the receptor-associated protein kinase in intact $\mathrm{H}-35$ hepatoma cells. Proc Natl Acad Sci USA 84:3137-3140, 1987.

156. Kasuga M, Karlsson FA, Kahn CR: Insulin stimulates the phosphorylation of the 95,000 -dalton subunit of its own receptor. Science 215:185-187, 1982

157. Rosen OM: After insulin binds. Science 237:1452-1458, 1987.

158. McDonald JD, Dohrmann GJ: Molecular biology of brain tumors. Neurosurgery 23:537-544, 1988.

159. Tran R, Kashmiri SVS, Kantor J, Greiner JW, Pestka S, Shively JE, Schlom J: Correlation of DNA hypomethylation with expression of carcinoembryonic antigen in human colon carcinoma cells. Cancer Res 48:5674-5679, 1988.

160. Cordon J, Wasylyk B, Buchwalder A, Sassone-Corsi P, Kedinger C, Chambon P: Promoter sequences of eukaryotic protein-coding genes. Science 209:1406-1414, 1980.

161. Anderson SJ, Chou HS, Loh DY: A conserved sequence in the T-cell receptor $\beta$-chain promoter region. Proc Natl Acad Sci USA 85: 3551-3554, 1988

162. Kudo A, Melchers $F$ : $A$ second gene, $V_{\text {pre } B}$ in the $\lambda_{5}$ locus of the mouse, which appears to be selectively expressed in pre-B lymphocytes. EMBO J 6:2267-2272, 1987.

163. Smale ST, Baltimore D: The "initiator" as a transcription control element. Cell 57:103-113, 1989.

164. Biggin MD, Tjian R: Transcription factors that activate the Ultrabithorax promoter in developmentally staged extracts. Cell 53:699$711,1988$.

165. Perkins KK, Dailey GM, Tjian R: In vitro analysis of the Antennapedia P2 promoter: identification of a new Drosophila transcription factor. Genes Dev 2:1615-1626, 1988.
166. Soeller WC, Poole SJ, Kornberg T: In vitro transcription of the Drosophila engrailed gene. Genes Dev 2:68-81, 1988

167. Schrewe H: Strukturanalyse des karzinoembryonalen Antigen (CEA)Gens und Charakterisierung seines Promotors durch funktionelle Analysen. Doctoral thesis, University of Freiburg, 1990.

168. Fritsch EF, Lawn RM, Maniatis T: Molecular cloning and characterization of the human $\beta$-like globin gene cluster. Cell 19:959-972, 1980.

169. DeRobertis EM, Oliver G, Wright CVE: Homeobox genes and the vertebrate body plan. Sci Am 263:26-32, 1990.

170. Kuroki M, Shinoda T, Takayasu T, Koga Y, Matsuoka Y: Immunological characterization and structural studies of normal fecal antigen-1 related to carcinoembryonic antigen. Mol Immunol 19:399-406, 1982.

171. Leon JA, Mesa-Tejada R, Gutierrez MC, Estabrook A, Greiner JW, Schlom J, Fisher PB: Increased surface expression and shedding of tumor associated antigens by human breast carcinoma celis treated with recombinant human interferons or phorbol ester tumor promoters. Anticancer Res 9:1639-1647, 1989.

172. Greiner JW, Horan Hand P, Noguchi P, Fisher PB, Pestka S, Schlom $\mathrm{J}$ : Enhanced expression of surface tumor-associated antigens on human breast and colon tumor cells after recombinant human leukocyte $\alpha$-interferon treatment. Cancer Res 44:3208-3214, 1984.

173. Greiner JW, Fisher PB, Pestka S, Schlom J: Differential effects of recombinant human leukocyte interferons on cell surface antigen expression. Cancer Res 46:4984-4990, 1986.

174. Guadagni F, Witt PL, Robbins PF, Schlom J, Greiner JW: Regulation of carcinoembryonic antigen expression in different human colorectal tumor cells by interferon gamma. Cancer Res 50:6248-6255, 1990.

175. Yamaguchi N, Kawai K: Factors affecting the CEA secretion of human adenocarcinoma cell lines into the spent medium. Gastroenterol Jpn $18: 428-435,1983$

176. Hager JC, Gold DV, Barbosa JA, Fligiel Z, Miller F, Dexter DL: $\mathrm{N}, \mathrm{N}$-Dimethylformamide-induced modulation of organ- and tumorassociated markers in cultured human colon carcinoma cells. $J$ Natl Cancer Inst 64:439-446, 1980.

177. Hwang WI, Sack TL, Kim YS: Effects of cyclic adenosine 3':5'-monophosphate upon glycoprotein and carcinoembryonic antigen synthesis and release by human colon cancer cells. Cancer Res 46:3371-3374, 1986

178. Tsao D, Shi Z-R, Wong A, Kim YS: Effect of sodium butyrate on carcinoembryonic antigen production by human colonic adenocarcinoma cells in culture. Cancer Res 43:1217-1222, 1983.

179. Chou JY, Sartwell AD, Lei K-J, Plouzek CA: Effects of sodium butyrate on the synthesis of human pregnancy-specific $\beta 1$-glycoprotein. $J$ Biol Chem 265:8788-8794, 1990

180. Toribara NW, Sack TL, Gum JR, Ho SB, Shively JE, Wilson JKV, Kim YS: Heterogeneity in the induction and expression of carcinoembryonic antigen-related antigens in human colon cancer cell lines. Cancer Res 49:3321-3327, 1989.

181. Chakrabarty S, Tobon A, Varani J, Brattain MG: Induction of carcinoembryonic antigen secretion and modulation of protein secretion/expression and fibronectin/laminin expression in human colon carcinoma cells by transforming growth factor $-\beta$. Cancer Res 48 : 4059-4064, 1988.

182. Chakrabarty S, Fan D, Varani J: Modulation of differentiation and proliferation in human colon carcinoma cells by transforming growth factor $\beta 1$ and $\beta 2$. Int $J$ Cancer 46:493-499, 1990.

183. Niles RM, Wilhelm SA, Thomas $P$, Zamcheck N: The effect of sodium butyrate and retinoic acid on growth and CEA production in a series of human colorectal tumor cell lines representing different states of differentiation. Cancer Invest 6:39-45, 1988.

184. Cunningham BA, Hemperly JJ, Murray BA, Prediger EA, Brackenbury R, Edelman GM: Neural cell adhesion molecule: structure, immunoglobulin-like domains, cell surface modulation, and alternative RNA splicing. Science 236:799-806, 1987.

185. Barthels D, Santoni M-J, Wille W, Ruppert C, Chaix J-C, Hirsch M-R, 
Fontecilla-Camps JC, Goridis C: Isolation and nucleotide sequence of mouse NCAM cDNA that codes for a $M_{r} 79,000$ polypeptide without a membrane-spanning region. $E M B O J 6: 907-914,1987$.

186. Lai C, Brow MA, Nave K-A, Noronha AB, Quarles RH, Bloom FE, Milner RJ, Sutcliffe JG: Two forms of 1B236/myelin-associated glycoprotein, a cell adhesion molecule for postnatal neural development, are produced by alternative splicing. Proc Natl Acad Sci USA 84:4337-4341, 1987.

187. Salzer JL, Holmes WP, Colman DR: The amino acid sequences of the myelin-associated glycoproteins: Homology to the immunoglobulin gene superfamily. J Cell Biol 104:957-965, 1987.

188. Sewell WA, Brown MH, Dunne J, Owen MJ, Crumpton MJ: Molecular cloning of the human T-lymphocyte surface CD2 (T11) antigen. Proc Natl Acad Sci USA 83:8718-8722, 1986.

189. Williams AF, Barclay AN, Clark SJ, Paterson DJ, Willis AC: Similarities in sequences and cellular expression between rat CD2 and CD4 antigens. J Exp Med 165:368-380, 1987.

190. Staunton DE, Marlin SD, Stratowa C, Dustin ML, Springer TA: Primary structure of ICAM-1 demonstrates interaction between members of the immunoglobulin and integrin supergene families. Cell 52:925933,1988

191. Staunton DE, Dustin ML, Springer TA: Functional cloning of ICAM-2, a cell adhesion ligand for LFA-1 homologous to ICAM-1. Nature 339:61-64, 1989.

192. Yarden Y, Escobedo JA, Kuang W-J, Yang-Feng TL, Daniel TO, Tremble PM, Chen EY, Ando ME, Harkins RN, Francke U, Fried VA, Ullich A, Williams LT: Structure of the receptor for platelet-derived growth factor helps define a family of closely related growth factor receptors. Nature 323:226-232, 1986.

193. Lewis VA, Koch T, Plutner H, Mellman I: A complementary DNA clone for a macrophage-lymphocyte Fc receptor. Nature 324:372-375, 1986.

194. Ravetch JV, Luster AD, Weinshank R, Kochan J, Pavlovec A, Portnoy DA, Hulmes J, Pan Y-CE, Unkeless JC: Structural heterogeneity and functional domains of murine immunoglobulin G Fc receptors. Science 234:718-725, 1986.

195. Tingström A, Blikstad I, Aurivillius M, Öbrink B: C-CAM (cell-CAM $105)$ is an adhesive cell surface glycoprotein with homophilic binding properties. J Cell Sci $96: 17-25,1990$.

196. Takeichi M: Cadherins: a molecular family essential for selective cellcell adhesion and animal morphogenesis. TIG 3:213-217, 1987.

197. Takeichi M: The cadherins: cell-cell adhesion molecules controlling animal morphogenesis. Development 102:639-655, 1988.

198. Edelman GM: Cell adhesion molecules in the regulation of animal form and tissue pattern. Annu Rev Cell Biol 2:81-116, 1986.

199. Ahnen DJ, Nakane PK, Brown WR: Ultrastructural localization of carcinoembryonic antigen in normal intestine and colon cancer. Cancer 49:2077-2090, 1982.

200. Ruoslahti E, Pierschbacher MD: New perspectives in cell adhesion: RGD and integrins. Science 238:491-497, 1987.

201. Bischof P: Schwangerschaftsprotein 1. Contrib Gynecol Obstet 12:6-92, 1984.

202. Leusch H-G, Hefta SA, Drzeniek Z, Hummel K, Markos-Pusztai Z, Wagener C: Escherichia coli of human origin binds to carcinoembryonic antigen (CEA) and non-specific crossreacting antigen (NCA). FEBS Lett 261:405-409, 1990.

203. Pignatelli M, Durbin H, Bodmer WF: Carcinoembryonic antigen functions as an accessory adhesion molecule mediating colon epithelial cell-collagen interactions. Proc Natl Acad Sci USA 87:1541-1545, 1990a.

204. Jones PCT: A contractile protein model for cell adhesion. Nature 212:365-369, 1966

205. Freyer DR, Boxer LA, Axtell RA, Todd RF III: Stimulation of human neutrophil adhesive properties by adenine nucleotides. $J$ Immunol $141: 580-586,1988$.
206. Capecchi MR: The new mouse genetics: Altering the genome by gene targeting. $T I G$ 5:70-76, 1989.

207. Thomas P, Toth CA, Saini KS, Jessup JM, G Steele, Jr.: The structure, metabolism and function of the carcinoembryonic antigen gene family. Biochim Biophys Acta 1032:177-189, 1990.

208. Hostetter RB, Augustus LB, Mankarious R, Chi K, Fan D, Toth C, Thomas P, Jessup JM: Carcinoembryonic antigen as a selective enhancer of colorectal cancer metastasis. JNCI 82:380-385, 1990

209. Goldenberg DM: Challenges to the therapy of cancer with monoclonal antibodies. JNCI 83:78-79, 1991.

210. Beidler BC, Ludwig JR, Cardenas J, Phelps J, Papworth CG, Melcher E, Sierzega M, Myers LJ, Unger BW, Fisher M, David GS, Johnson MJ: Cloning and high level expression of a chimeric antibody with specificity for human carcinoembryonic antigen. J Immunol 141:40534060, 1988.

211. Hardman N, Gill LL, de Winter RFJ, Wagner K, Hollis M, Businger F, Ammaturo D, Buchegger F, Mach J-P, Heusser C: Generation of a recombinant mouse-human chimaeric monoclonal antibody directed against human carcinoembryonic antigen. Int J Cancer 44:424-433, 1989.

212. Neumaier M, Shively L, Chen F-S, Gaida F-J, Ilgen C, Paxton RJ, Shively JE, Riggs AD: Cloning of the genes for T84.66, an antibody that has a high specificity and affinity for carcinoembryonic antigen, and expression of chimeric human/mouse T84.66 genes in myeloma and Chinese hamster ovary cells. Cancer Res 50:2128-2134, 1990.

213. Tsujisaki M, Imai K, Tokuchi S, Ono A, Takai Y, Nakata M, Sugiyama $T$, Yachi A: Idiotype analysis and immune response with use of antiidiotypic monoclonal antibody to anti-CEA antibody. In The Carcinoembryonic Antigen Gene Family. A Yachi, JE Shively, eds. Elsevier Science Publishers, BV, Amsterdam, 1989, p 119-129.

214. Losman MJ, Monestier M, Hansen HJ, Goldenberg DM: Baboon antiidiotype antibodies mimic a carcinoembryonic antigen epitope. Int J Cancer 46:310-314, 1990.

215. Bhattacharya-Chatterjee M, Mukerjee S, Biddle W, Foon KA, Köhler $\mathrm{H}$ : Murine monoclonal anti-idiotype antibody as a potential network antigen for human carcinoembryonic antigen. $J$ Immunol 145:27582765, 1990.

216. Boucher D, Cournoyer D, Fuks A, Stanners CP; Molecular cloning of cDNA clones corresponding to a new CEA Member expressed in leukocytes. XVIIth Meeting of the International Society for Oncodevelopmental Biology and Medicine, Freiburg, 1989.

217. Streydio $C$, Lacka $K$, Swillens $S$, Vassart G: The human pregnancyspecific $\beta 1$-glycoprotein (PS $\beta$ G) and the carcinoembryonic antigen (CEA)-related proteins are members of the same multigene family. Biochem Biophys Res Commun 154:130-137, 1988.

218. Chan W-Y, Tease LA, Borjigin J, Chan P-K, Rennert OM, Srinivasan B, Shupert WL, Cook RG: Pregnancy-specific $\beta 1$ glycoprotein mRNA is present in placental as well as non-placental tissues. Hum Reprod 3:677-685, 1988.

219. Watanabe S, Chou JY: Molecular heterogeneity of human pregnancyspecific $\beta 1$-glycoprotein. In Placental and Endometrial Proteins. S Mizutani, ed. VNU Science Press BV, Utrecht, Netherlands, 1988, p 155-158.

220. Rooney BC, Horne CHW, Hardman N: Molecular cloning of a cDNA for human pregnancy-specific $\beta 1$-glycoprotein: homology with human carcinoembryonic antigen and related proteins. Gene 71:439-449, 1988.

221. McLenachan T, Mansfield B: Expression of CEA-related genes in the first trimester human placenta. Biochem Biophys Res Commun 162: 1486-1493, 1989.

222. Arakawa F, Kuroki M, Misumi Y, Matsuoka Y: New members of cDNA clones belonging to pregnancy-specific $\beta$ I glycoprotein (PS $\beta G$ ). XVIIth Meeting of the International Society for Oncodevelopmental Biology and Medicine, Freiburg, 1989

223. Khan WN, Hammarström S: Identification of a new carcinoembryonic 
antigen (CEA) family member in human fetal liver-Cloning and sequence determination of pregnancy-specific glycoprotein 7. Biochem Biophys Res Commun 168:214-225, 1990.

224. Kuroki M, Kuroki M, Ichiki S, Matsuoka Y: Identification and partial characterization of the unglycosylated peptide of carcinoembryonic antigen synthesized by human tumor cell lines in the presence of tunicamycin. Mol Immunol 21:743-746, 1984

225. Siepen D, Paxton RJ, Neumaier M, Shively JE, Wagener C: Carcinoembryonic antigen (CEA) and two crossreacting antigens of $165 \mathrm{kD}$ and $105 \mathrm{kD}$ isolated from meconium exhibit identical amino terminal sequences. Biochem Biophys Res Commun 147:212-218, 1987.

226. Burtin P, Chavannel G, Hirsch-Marie H: Characterization of a second normal antigen that cross-reacts with CEA. JImmunol 111:1926-1928, 1973.

227. Neumaier M, Fenger U, Wagener $\mathbf{C}$ : Monoclonal antibodies for carcinoembryonic antigen (CEA) as a model system: Identification of two novel CEA-related antigens in meconium and colorectal carcinoma tissue by western blots and differential immunoaffinity chromatography. J Immunol 135:3604-3609, 1985.

228. Audette M, Buchegger F, Schreyer M, Mach J-P: Monoclonal antibody against carcinoembryonic antigen (CEA) identifies two new forms of cross-reacting antigens of molecular weight 90,000 and 160,000 in normal granulocytes. Mol Immunol 24:1177-1 186, 1987.
229. Svenberg T, Hammarström S, Hedin A: Purification and properties of biliary glycoprotein I (BGP I). Immunochemical relationship to carcinoembryonic antigen. Mol Immunol 16:245-252, 1979.

230. Grunert F, AbuHarfeil N, Schwarz K, von Kleist S: Two CEA and three NCA species, although distinguishable by monoclonal antibodies, have nearly identical peptide patterns. Int J Cancer 36:357-362, 1985.

231. Schwarz K, Mehnert-Solzer C, von Kleist S, Grunert F: Analysis of the specificity of CEA reactive monoclonal antibodies. Immunological support for the domain-model of CEA. Mol Immunol 25:889-898, 1988.

232. Kuroki M, Matsuo Y, Kuroki M, Matsuoka Y: Nonspecific crossreacting antigen (NCA) expressed by human granulocytes: Six species with different peptide sizes and membrane anchoring forms. Biochem Biophys Res Commun 166:701 -708, 1990.

233. Kuroki M, Kuroki M, Moore GE, Ichiki S, Matsuoka Y: The molecular heterogeneity of nonspecific cross-reacting antigen synthesized by tumor cells and granulocytes. Jpn J Cancer Res (Gann) 79:82-90, 1988.

234. Kuroki M, Matsuo Y, Ohtani T, Minowada J, Kuroki M, Matsuoka Y: A novel CEA-cross-reacting antigen of molecular weight 140,000 expressed on human lymphoid cell lines. Mol Immunol 27: $689-696,1990$. 